\title{
Oxfordian neptunian dykes with brachiopods from the southern part of the Kraków-Częstochowa Upland (southern Poland) and their links to hydrothermal vents
}

\author{
Jacek Matyszkiewicz ${ }^{1}$ - Marcin Krajewski ${ }^{1}$ Alicja Kochman ${ }^{1}$ Andrzej Kozłowski ${ }^{2}$. \\ Marek Duliński ${ }^{3}$
}

Received: 20 September 2015 / Accepted: 19 February 2016 / Published online: 9 March 2016

(C) The Author(s) 2016. This article is published with open access at Springerlink.com

\begin{abstract}
Neptunian dykes with abundant brachiopods, cf. Lacunosella sp. and fragments of echinoderms, occur in Oxfordian limestones in the southern part of the KrakówCzęstochowa Upland. The dykes fill fissures that have opened in the massive limestones due to local extension of the sedimentary basin located along the northern, passive margin of the Tethys Ocean. These fissures transmitted warm hydrothermal solutions that controlled the mass growth of free-living bacteria and microbial mats feeding the fauna, mostly brachiopods and echinoderms, settling the seafloor around the fissures. For some time, the fissures remained empty and their vertical walls were settled by stromatolites. Infilling of the fissures was an abrupt event related to faulting in the Oxfordian and to the rejuvenation of dislocations cutting through the Paleozoic basement.
\end{abstract}

Alicja Kochman

kochman@geol.agh.edu.pl

Jacek Matyszkiewicz

jamat@geol.agh.edu.pl

Marcin Krajewski

kramar@geolog.geol.agh.edu.pl

Andrzej Kozłowski

a.j.kozlowski@uw.edu.pl

Marek Duliński

marek.dulinski@fis.agh.edu.pl

1 Faculty of Geology, Geophysics and Environment Protection, AGH University of Science and Technology, al. Mickiewicza 30, 30-059 Kraków, Poland

2 Faculty of Geology, University of Warsaw, ul. Żwirki i Wigury 93, 02-089 Warsaw, Poland

3 Faculty of Physics and Applied Computer Science, AGH University of Science and Technology, ul. Kawiory 26a, 30-059 Kraków, Poland
Then, in the Cretaceous, and primarily in the Cenozoic, tectonic discontinuities filled with neptunian dykes were penetrated by karst waters and by hydrothermal solutions, which partly silicified the carbonate material infilling the dykes. The formation of dykes is genetically related to the Late Jurassic, Pan-European stress-field reorganization caused by the opening of the Northern Atlantic and Tethys Oceans.

Keywords Neptunian dykes · Hydrothermal vents . Brachiopods · Upper Jurassic

\section{Introduction}

Neptunian dykes are defined as fissures within rocks exposed on the sea bottom that have been filled with submarine sediments (Flügel 2004). The formation of such fissures is interpreted as an effect of: (1) depositional processes, (2) synsedimentary features, (3) diagenetic transformations of sediments, and, above all, (4) extensional tectonics in the sedimentary basin (see e.g., Land and Goreau 1970; Wendt 1971; Smart et al. 1988; Martire 1996; Winterer et al. 1991; Santantonio 1993; Winterer and Sarti 1994; Molina et al. 1995; Wieczorek and Olszewska 2001; Łuczyński 2001; Flügel 2004; Wall and Jenkyns 2004; Črne et al. 2007; Montenat et al. 2007; Kandemir and Yilmaz 2009; Kołodziej et al. 2010; Reolid and Molina 2010; Reolid et al. 2010; Nieto et al. 2012; Barski 2012).

The Upper Jurassic neptunian dykes hosted in carbonate succession from the southern part of the KrakówCzęstochowa Upland (KCU) have already been described in several short announcements (Hoffmann and Matyszkiewicz 1989; Wieczorek and Krobicki 1994; Koszarski 1995; Krajewski 2004; Krajewski and Matyszkiewicz 
2004; Jędrys and Krajewski 2007), but their development has never been studied in detail. Neptunian dykes cutting through the Oxfordian microbial-sponge carbonate buildups were encountered in quarries in Młynka and Czajowice as well as in the Pradnik River and Beqdkowice Valleys. Among them were dykes filled with brachiopods Rhynchonella sp. (Wieczorek and Krobicki 1994; Krajewski 2004) or with carbonate detrital material (Koszarski 1995; Krajewski 2004; Krajewski and Matyszkiewicz 2004; Jędrys and Krajewski 2007).

Although brachiopods are common in Oxfordian sediments of the KCU, their accumulations are rather unique. In the literature, several species were identified: Lacunosella cracoviensis (Quenstedt) and rare L. arolica (Oppel), L. trilobata formis Wiśniewska, Septaliphoria astieriana (d'Orbigny), S. moravica (Uhlig), Sellithyris engeli (Rollier), Zeilleria delmontana (Oppel) and Terebratulina substriata (Schlotheim) (Różycki 1948; Wierzbowski 1970; Wiśniewska-Żelichowska 1971; Heliasz and Racki 1980). In Oxfordian microbial-sponge buildups, the most common are L. cracoviensis, S. astieriana and T. substriata (Różycki 1948; Wiśniewska-Żelichowska 1971; Heliasz and Racki 1980), whereas in inter-buildup sediments, S. engeli, Z. delmontana, and $S$. moravica were found (Heliasz and Racki 1980). In the southern part of KCU, the dominant form is $L$. cracoviensis, characterized by local morphotypes (Różycki 1948) of mostly symmetric shells and average sizes significantly larger than those observed in the northern KCU, where asymmetric forms prevail (Różycki 1948; Wierzbowski 1970; Heliasz and Racki 1980). Presumably, this species predominates in sediments filling the studied neptunian dykes.

In recent years, exploration in the Big (Polish: Duża) Cave located in the slope of the Kluczwoda Valley discovered a neptunian dyke filled with numerous brachiopods (Nowak 2014). This work presents the development of unique dykes filled with brachiopods discovered in only three localities: (1) in the operating Młynka Quarry, (2) in the Big Cave in the Kluczwoda Valley and (3) in the Grodzisko Rock in the Pradnik River Valley (Fig. 1). Field observations, combined with the results of microfacies and geochemical analyses and cathodoluminescence, isotopic and fluid inclusion studies, enabled us to reconstruct the formation of these neptunian dykes, and to discuss the regional context of their occurrence.

\section{Geological setting}

The KCU is located in southern Poland and belongs to the regional tectonic unit known as the Silesian-Kraków Homocline (SKH), built of Triassic, Jurassic, and Cretaceous sediments (Fig. 1). Here, Mesozoic strata unconformably cover Precambrian and Paleozoic formations cut by the Kraków-Lubliniec Fault Zone (KLFZ) and the somewhat younger Krzeszowice-Charsznica Fault, which displaces it (Habryn et al. 2014). The KLFZ, active since the Early Paleozoic (Morawska 1997; Żaba 1999), is accompanied by manifestation of Paleozoic intrusions. Some of the intrusions became erosionally exposed in the Oxfordian forming topographic highs upon the sea bottom. The areas underlain by those intrusions whose top parts were not eroded revealed less intense subsidence as compared to the neighboring areas, thereby creating structural highs upon the sea bottom, which became colonized by benthic organisms (Matyszkiewicz et al. 2006a).

Upper Jurassic carbonates were deposited on the passive shelf of the northern margin of the Tethys Ocean, to which the KCU also belongs. They represent a transgressiveregressive, Callovian-Lower Kimmeridgian tectono-stratigraphic unit (Kutek 1994) and are developed as microbialsponge megafacies, which comprises bedded and massive facies as well as submarine gravity flows (Fig. 2; Matyszkiewicz et al. 2015b).

\section{Bedded facies}

The Upper Jurassic succession (Fig. 2) begins with a series of thin-bedded marls and alternating limestones with abundant benthic and nektonic fauna of the Early and early Middle Oxfordian ages. These strata grade upwards into a strongly differentiated limestone complex. Sediments of the Middle Oxfordian bedded facies represent thin- to medium-bedded pelitic limestones locally intercalated with marls and thin calciturbidites. The upper Middle Oxfordian and Upper Oxfordian successions are dominated by thick-bedded limestones with flints. The topmost part of the Upper Jurassic section of the Lower Kimmeridgian age is composed of bedded limestone-marl strata, known mostly from well logs (Burzewski 1969).

\section{Massive facies}

The massive facies comprise various types of carbonate buildups (terminology after Riding 2002), as well as olistoliths separated from massive limestone complexes and embedded within debris flow deposits. Carbonate buildups started to develop at the end of the Early and beginning of the Middle Oxfordian (Fig. 2) as small, spongemicrobial, low-relief carbonate mud mounds without rigid frameworks. These mounds then evolved over time into: (1) microbial-sponge segment reefs with laminar frameworks; (2) filled frame reefs with initial, reticulate rigid frameworks, which, in turn, were later replaced by (3) open frame reefs with well-developed reticulate rigid frameworks (Matyszkiewicz et al. 2012). Development 
Fig. 1 Localization of Oxfordian neptunian dykes with brachiopods in the southern part of the Kraków-Częstochowa Upland (KCU) with reference to a bedrock map (after Gradziński 2009, simplified and modified). The Kraków-Lubliniec Fault Zone (KLFZ) and the younger Krzeszowice-Charsznica Fault $(\mathrm{KChF})$, which displaces the KLFZ both cut through the Paleozoic basement of Mesozoic formations. Positions of the KLFZ and $\mathrm{KChF}$ after Habryn et al. (2014)

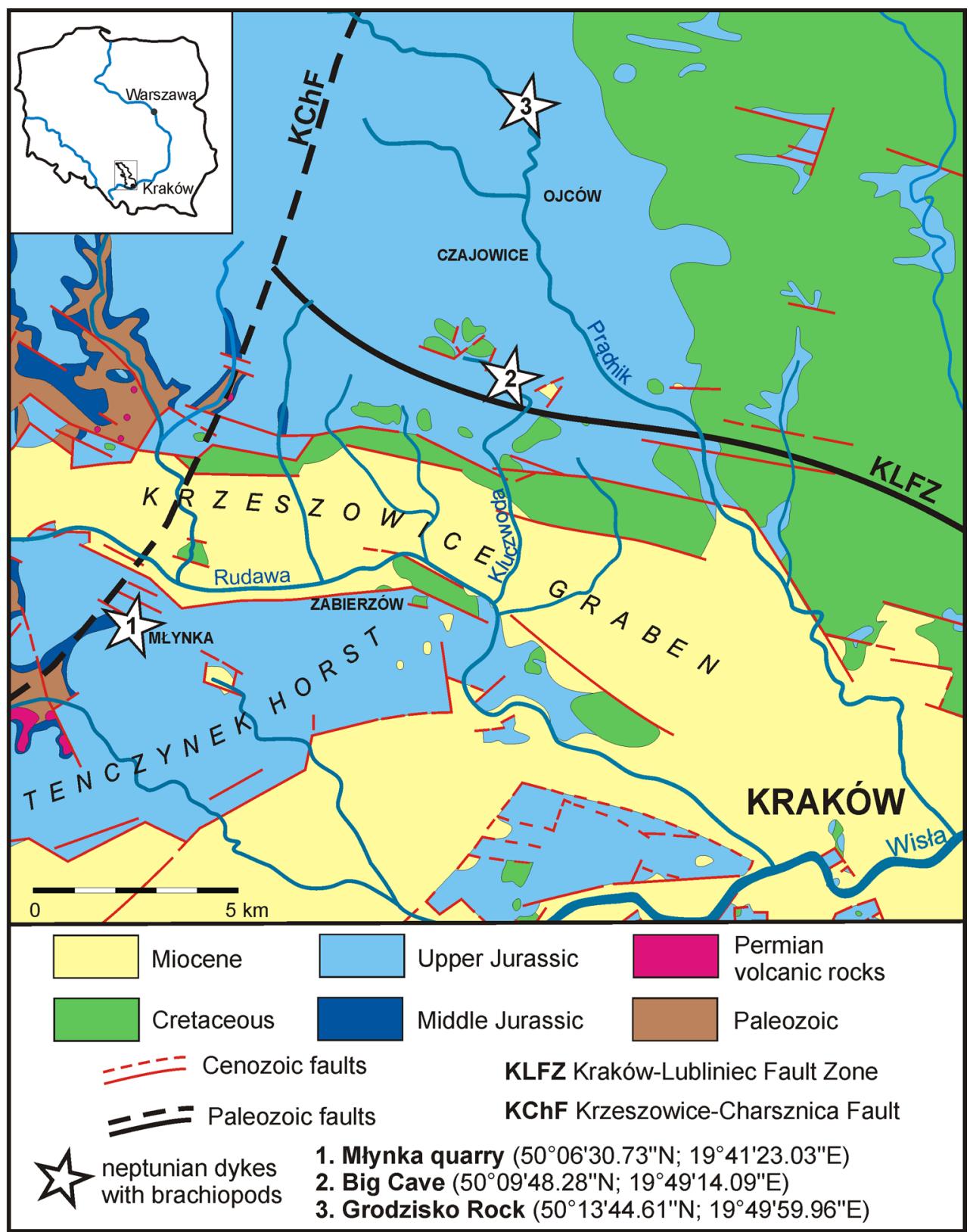

of carbonate buildups attained its climax at the end of the Middle and beginning of the Late Oxfordian. Carbonate buildups began to disappear in the Late Oxfordian and sea bottom relief became partly leveled.

\section{Sediment gravity flows}

Sediment gravity flows are common throughout the Upper Jurassic succession, being particularly spectacular at the break between the Oxfordian and the Lower Kimmeridgian (Fig. 2). These are mostly debris flow sediments and calciturbidites. Their occurrence is associated with the temporary deterioration of conditions controlling the growth of carbonate buildups, coeval, active, synsedimentary tectonics (Matyszkiewicz 1996, 1997), and sea-level fluctuations. Debris flow sediments were observed particularly along the margins of the tectonic horsts (Matyszkiewicz 1996; Ziółkowski 2007; Matyszkiewicz et al. 2012), where the best conditions for observation are.

\section{Materials and methods}

Two neptunian dykes with abundant brachiopods were exposed in the 1980s and 1990s at the operating Młynka Quarry (MQ). Unfortunately, these dykes have not survived; however, the authors possess about 20 samples collected from their infillings. 

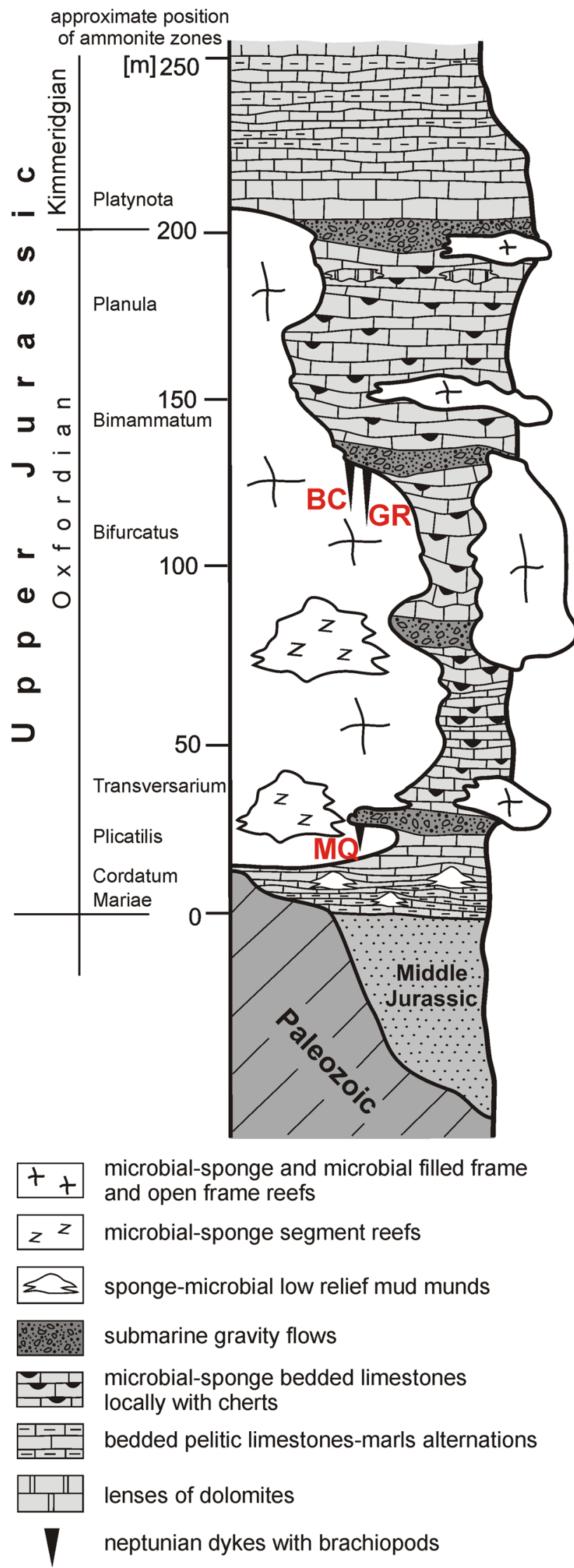

microbial-sponge and microbial filled frame and open frame reefs

microbial-sponge segment reefs

sponge-microbial low relief mud munds

submarine gravity flows

microbial-sponge bedded limestones locally with cherts

bedded pelitic limestones-marls alternations

lenses of dolomites

neptunian dykes with brachiopods
4Fig. 2 Lithostratigraphic column of Upper Jurassic strata in the southern part of the Kraków-Częstochowa Upland with the stratigraphic position of neptunian dykes with brachiopods (after Matyszkiewicz et al. 2012; modified): $M Q$ Młynka Quarry, $B C$ Big Cave, $G R$ Grodzisko Rock

The Big Cave (BC) site in the Mączna Rock was discovered in the years 2013-2014 in the course of the exploration of a cave located in the eastern slope of the Kluczwoda Valley (Nowak 2014; Wrzak 2014). This is the only available neptunian dyke with brachiopods from which 25 samples were collected from the infilling material and the host rock.

The last-studied neptunian dyke was exposed for a short time in 2001 in the Grodzisko Rock (GR), located in the northern slope of the Pradnik River Valley, in an excavation dug for the construction of a house (Krajewski 2004). At this site, several samples were collected of the brachiopodrudstone and the host rock.

From samples collected at the MQ and BC sites, 25 thin-sections and 15 polished sections, which served as the basic materials for microfacies analysis, were prepared. Thin-sections from both the MQ and $\mathrm{BC}$ sites were subjected to CL examinations; in those from the $\mathrm{BC}$ site, additional measurements of FI homogenization temperatures were made in quartz crystals and microprobe analyses of cements were carried out. Material was collected from both the MQ and BC samples for geochemical and $\mathrm{Nd}$ isotope analyses.

The principal geochemical analyses were carried out at Activation Laboratories Ltd. (ACTLABS) in Ancaster (Canada) using fusion-inductively coupled plasma (FUSICP) for ten samples from the BC and two others from the MQ sites.

The CL analyses were carried out on polished, uncovered thin-sections with an $8300 \mathrm{Mk}$ III cold cathode instrument at the Institute of Geological Sciences, Polish Academy of Sciences, in Kraków.

Measurements of FI homogenization temperatures $\left(T_{\mathrm{h}}\right)$ in quartz were carried out at the immersion heating stage (Kozłowski et al. 1979). In total, 52 inclusions were measured, following the principles established by Roedder (1984). The freezing runs yielded data enabling calculation of the concentrations of salts in the fluids (Crawford 1981; Kozłowski 1984) and identification of the presence of carbon dioxide and methane in fluid inclusions. Each heating and cooling run was repeated three times; for interpretation, only those runs were used for which the obtained values were satisfactorily consistent (cf. Roedder 1984).

Microprobe analyses of carbonate cements were completed at the Laboratory of Critical Elements, Faculty of Geology, Geophysics and Environment Protection at the 


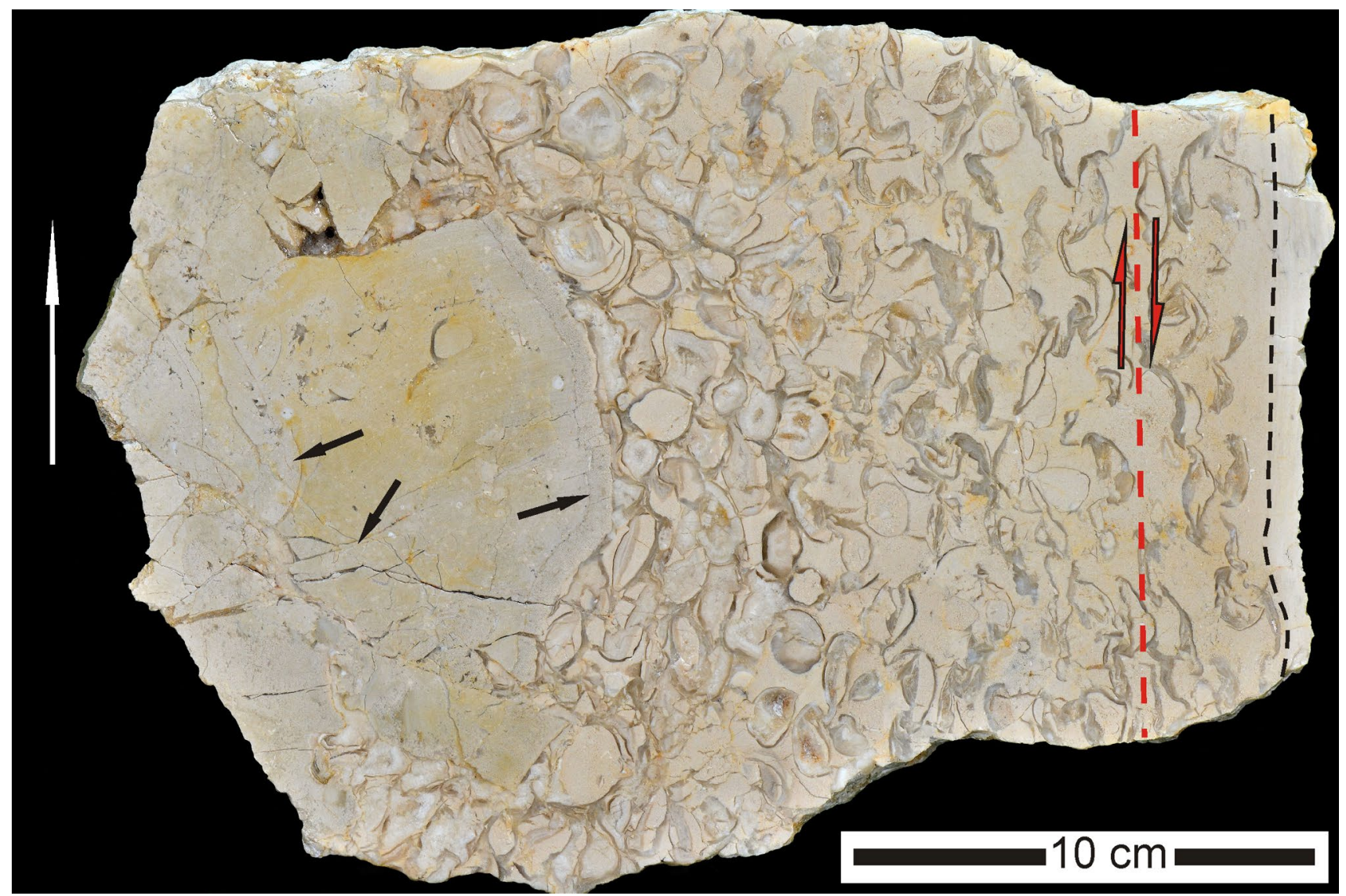

Fig. 3 Infilling of the MQ neptunian dyke. The top is indicated by white arrow. On the right: a laminated stromatolite covering the wall of fracture (contoured with dashed black line). At contact with the dyke wall, brachiopods show significant deformations and are elongated parallel to the wall of the dyke due to displacement along the

AGH University of Science and Technology in Kraków using a JEOL Super Probe JXA-8230.

$\mathrm{Nd}$ isotope studies were carried out at the Isotope Laboratory of the Adam Mickiewicz University in Poznań (Poland) with a Finnigan MAT 261 multi-collector thermal ionization mass spectrometer. Nine samples collected from the neptunian dyke at the $\mathrm{BC}$ site and two others taken from the MQ site were analyzed.

\section{The Młynka Quarry}

The Młynka Quarry is located at the southern margin of the Tenczynek Horst, which borders the Krzeszowice Graben to the south (Fig. 1). The exposed Lower and Middle Oxfordian succession includes zones from the Cordatum to the Transversarium (Głowniak 2006; Jurkowska and Kołodziej 2013). The Upper Jurassic sequence begins with marls with sponges and ammonites which grade upward into thin-bedded, pelitic limestones with marl intercalations (Fig. 2). A horizon of glauconitic marls occurs in fault (direction marked by red arrows). Towards the center of the dyke infilling, deformations of brachiopod shells decline. On the left: angular clasts of massive limestones with fragments of calcified siliceous sponges Hexactinellids (arrows)

the upper part of the pelitic limestones (Jurkowska and Kołodziej 2013), followed by massive limestones representing the Plicatilis-Transversarium zones and developed as microbial-sponge facies with siliceous sponges, bivalves, brachiopods, ammonites, bryozoans, and fragments of echinoderms, sometimes accompanied by numerous specimens of Crescentiella sp. (Hoffmann and Matyszkiewicz 1989). In the top portion of the quarry walls, debris flow with clasts of massive limestones is locally present.

Two neptunian dykes with attitudes N20W 90 and N10W 90 were exposed in the upper bench of the quarry. Both dykes were filled with densely packed brachiopods embedded within a light-beige matrix. The dykes cut through massive limestones in which ammonites were found, indicative of the Transversarium Zone (Głowniak 2006). The maximum thickness of the dykes was about $0.5 \mathrm{~m}$. The dykes covered the exposed surface of massive limestone, which was over a dozen meters long and up to $10 \mathrm{~m}$ high (Wieczorek and Krobicki 1994). 
The infilling material in dykes (Figs. 3, 4) exhibits both vertical and lateral variability. The walls of the dykes were covered by vertical stromatolite of about $1.5 \mathrm{~cm}$ in thickness (Figs. 3, 5a), which, along a 10-cm stretch, contact floatstone, which in turn fills the marginal parts of the dyke and changes into rudstone towards its centre. Stromatolite on the wall of massive limestone is composed of peloidal and micropeloidal lamina, 0.5 to $3 \mathrm{~mm}$ thick. The thicker lamina are composed of peloids and thinner of micropeloids (Fig. 5a). The lamina are parallel, but sometimes wavy also. Within lamina composed of micropeloids are occasionally observed oval single unidentified coprolites up to $0.8 \mathrm{~mm}$ in diameter.

In the floatstone, brachiopods found at contact with the massive limestone are greatly flattened and elongated parallel to the walls of the dyke (Fig. 3). Deformation of shells decreases towards the centre of the dyke. In the rudstone, brachiopod shells contact each other and preserve their oval shapes, but are sometimes crushed. Locally, in the central part of the dyke we observed angular clasts, up to $20 \mathrm{~cm}$ in diameter, developed as wackestone-packstone and boundstone with calcified siliceous sponges (Fig. 3).

In the matrix we identified Crescentiella morronensis, oncoids up to $0.5 \mathrm{~mm}$ in diameter, peloids, single bioclasts, unidentified coprolites, benthic foraminifera, and tuberoids (Fig. 5b-e). Locally, accumulations of peloids are present. The internal sediments filling the brachiopod shells show development similar to that of the enclosing matrix (Fig. 5c, d). In the latter, we identified additionally fragments of echinoderms up to several millimeters in diameter

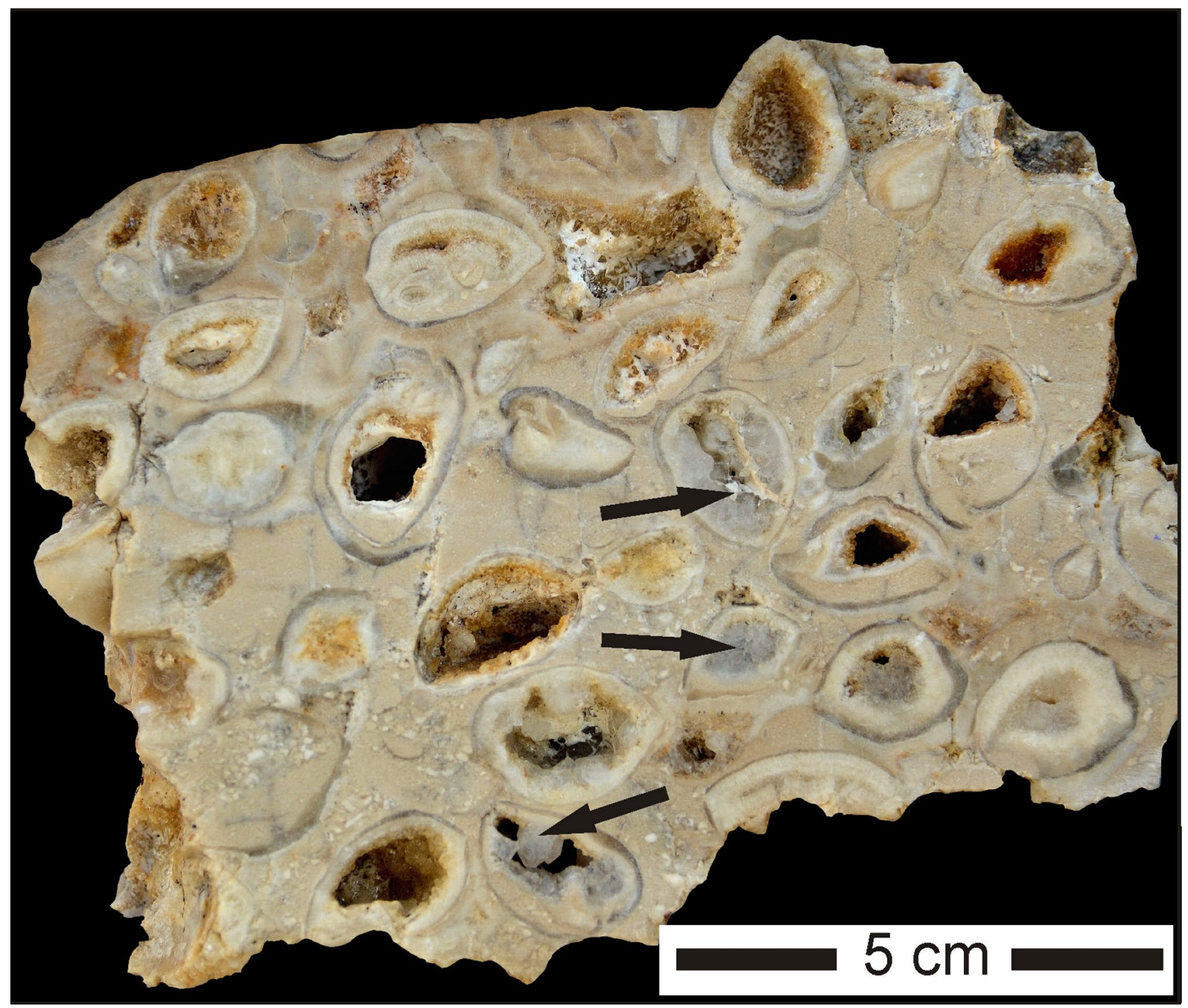

Fig. 4 Floatstone from the infilling of the MQ dyke. Brachiopod shells show varying degrees of infilling. Some are filled with coarse crystalline quartz (arrows). The matrix is wackestone-packstone or grainstone with echinoderm detritus 
(Fig. 5b) with thin microbial envelopes. The internal sediments, along with carbonate cement, fill the shells entirely or geopetally.

In flattened brachiopod shells located close to the walls of the dyke, the boundary between internal sediment and cements is vertical (Fig. 3). The orientation of the geopetal infillings of shells found in the central parts of the dykes is chaotic (Fig. 4). Some shells are empty; others are filled with carbonate cement or quartz.

In the largest shells, we sometimes observed juvenile forms of brachiopods up to several millimeters across (Fig. 5d). The surfaces and interiors of brachiopods shells contain diversified cements. The most common is radiaxial fibrous cement, which locally coats the shells from outside (Fig. 5d) but sometimes also covers the interiors, particularly if the shells are only partly filled with the internal sediment (Fig. 5e, f). In such cases, the radiaxial fibrous cement is usually covered with dogtooth cement. The internal surfaces of shells can also be covered with two other cements: (1) bladed and granular, sometimes found on the surfaces of internal sediment in partly filled shells (Fig. 5c) and (2) granular, observed in shells initially entirely filled with internal sediment which, however, contacts the shell walls at present, whereas the granular cement fills the centers of the shells (Fig. 5c). Occasionally, brachiopods shells are filled with granular quartz (Fig. 5e, f), which hosts only scarce fluid inclusions. Sporadically, the internal sediment infillings contain fine (up to $1 \mathrm{~mm}$ across) aggregates of microflamboyant quartz (Fig. 5c; Dong et al. 1995).

The walls of cavities embedded within the matrix are covered with radiaxial fibrous or bladed cements, whereas the centers are filled with granular and blocky calcite cements.

\section{The Big Cave}

The Big Cave at the Maczna Rock is located in the northern slope of the Kluczwoda Valley (Nowak 2014). The slopes of the valley are built of massive limestones developed as microbial-sponge and microbial-Crescentiella facies. Ammonites found in the adjacent outcrops indicate the Bifurcatus Zone (Ziółkowski 2007). Locally, the massive limestones are covered with debris flow deposits followed upward by bedded, lime-mud limestones with thin intercalations of marly limestones and marls (Matyszkiewicz and Krajewski 1996) representing the Bimammatum Zone (Ziółkowski 2007).

A neptunian dyke is exposed near the end of the Big Cave, in a corridor named 'the shell crack' (Nowak 2014). The corridor follows a vertical vein which can be observed for about $10 \mathrm{~m}$ in the roof and walls of the cave (Fig. 6). The attitude of the vein is N40W 90, its thickness $0.5 \mathrm{~m}$; its contact with the limestone is sharp. Along the limestone wall we observed fragments of vertically laminated stromatolites exhibiting vertical displacement (Fig. 7a).

The neptunian dyke is filled with floatstone (Fig. 7a-c) and, locally, with rudstone (Fig. 7c) containing brachiopod shells and other bioclasts, dominated by fragments of echinoid plates up to $5 \mathrm{~mm}$ in diameter usually overgrown with syntaxial calcite cement (Figs. 8a, e, f, 9d, 10a, b, e). These plates are sometimes completely silicified together with syntaxial cement (Fig. 8f). Rarely, the full tests of echinoids are preserved (Fig. 7b). Other bioclasts include numerous enigmatic microfossils such as Crescentiella morronensis, fragments of Terebella lapilloides, tuberoids with locally preserved fragments of calcified siliceous sponges, single benthic foraminifera (Reophax sp., Ammobaculites sp.), holothurian sclerites and belemnites. Apart from bioclasts, microoncoids up to $1 \mathrm{~mm}$ across, with unidentified fragments of bioclasts in the nuclei, are common. The microoncoids form local accumulations together with Crescentiella morronensis, single peloids, and small bioclasts up to $1 \mathrm{~mm}$ across. Bioclast surfaces are usually covered with films of isopachous granular cement, which grade towards the centers of the bioclasts into dogtooth cement contacting granular and blocky calcite cements (Fig. 10a, b). Locally, the fine-grained matrix of floatstones is replaced by microcrystalline granular quartz. We also observed aggregates of microflamboyant quartz, up to several millimeters across, which replaced echinoderm plates and cements (Fig. 8a).

In the matrix, cavities $1-2 \mathrm{~cm}$ long and $0.5 \mathrm{~cm}$ high are common, filled with internal sediment developed as irregularly laminated crystal silt with single bioclasts, mostly echinoderm plates embedded within syntaxial cement (Figs. 8a, 10c). The internal surfaces of cavity walls are occasionally covered with dogtooth cement (Fig. 8b-d). Sometimes the larger (several centimeters long) cavities are filled with coarse crystalline, granular quartz with the relics of blocky calcite cements. Two generations of this quartz occur: (1) granular quartz with abundant fluid inclusions at the walls of cavities and (2) inclusion-free, granular quartz (Fig. 10c, d).

The shells are: (1) empty; (2) geopetally filled with chaotic orientation; or (3) entirely filled with internal sediment, cement, or even coarse crystalline quartz (Fig. 7a-c). The interiors of brachiopod shells are entirely or partly filled with internal sediments and diversified carbonate cements (Fig. 10f) or by coarse crystalline, granular quartz (Fig. 10e). In the parts of shells filled with cements, over the internal sediments we observed granular and blocky calcite cements along with bladed calcite cement, the latter growing from the upper surface of the shells towards their centers (Fig. 10f). In geopetally filled shells, the internal sediments are mudstones in the lower parts of the shells (in situ) and packstones deposited immediately over the sediment, at the point of contact with the cement. Locally, 

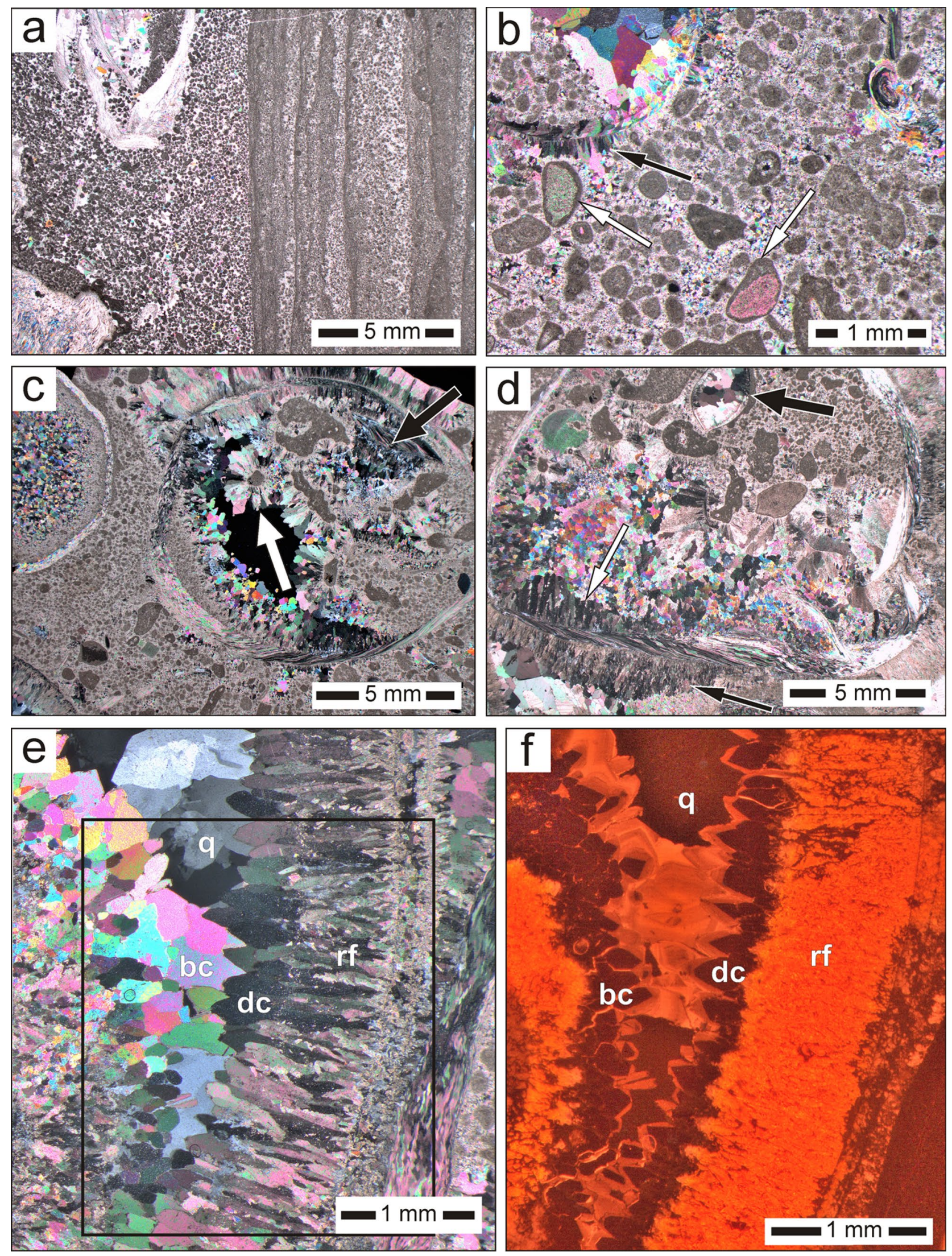
4Fig. 5 Microfacial development of the MQ neptunian dyke: a contact of stromatolites covering the surface of the fracture cutting through the massive limestone (right) with the infilling of the neptunian dyke developed as floatstone (left); b the matrix developed as packstonegrainstone encloses brachiopods with tuberoids, microoncoids and echinoderm plates. On the latter, microbial envelopes are seen (white arrows). On the outer surface of the shells occurs gravitative fibrous cement (black arrow). Crossed nicols; c floatstone with brachiopod shells. The interior of the larger shell (right), partly filled with internal sediment, developed as floatstone similar to the matrix occupying the spaces between shells. Crystals of bladed calcite cement are seen at the surface of the internal sediment (white arrow). Locally, microflamboyant quartz (black arrow) grows within the internal sediment. A fragment of a smaller shell (on the left) is entirely filled, but internal sediment was preserved only close to the dyke walls, whereas the centre was filled with granular cement. Crossed nicols; $\mathbf{d}$ a brachiopod shell is filled with internal sediment (in the upper part) with Crescentiella morronensis, echinoderm plates, microoncoids and the small shell of a juvenile brachiopod (big black arrow). In the lower part, three generations of cements are seen: radiaxial fibrous cement (white arrow) growing on the inner lower shell grading into granular cement towards the centre of an area covered with cements and gravitative fibrous cement (small black arrow) on the outer shell. Crossed nicols; $\mathbf{e}$ on the inner surface of the shell, radiaxial fibrous cement $(r f)$ overgrown by dogtooth cement $(d c)$ are observed. The shell's interior is filled with coarse crystalline, inclusion-free quartz $(q)$ and blocky calcite cement $(b c)$. Crossed nicols; f CL image of brachiopod shell infilling. Radiaxial fibrous cement $(r f)$ is covered with non-luminescent, marine, phreatic dogtooth cement $(d c)$, which shows intensely red luminescence only in the outer zones of crystals. The centre of the shell is filled with blocky calcite cement $(b c)$ with a zonal structure and bright luminescent color and by non-luminescent quartz $(q)$

aggregates of microflamboyant quartz can be found in brachiopod shells (Fig. 10f).

Some brachiopod shells are crushed and displaced along with infilling internal sediment (Fig. 10f). The cracks along which displacements proceeded are filled with blocky calcite cement. Displacement was also observed in an echinoderm spine whose fragments were moved against each other along a narrow crack filled with granular cement and quartz with relics of blocky calcite cement (Fig. 9d).

The silicification process observed within of the brachiopod shells (Fig. 10e) produced three types of infillings: (1) granular quartz crystals of diameters up to about $2 \mathrm{~mm}$, entirely filling the shell; these quartz crystals host rare fluid inclusions; (2) large (up to $5 \mathrm{~mm}$ across) quartz crystals with numerous fluid inclusions; and (3) irregularly distributed aggregates of microflamboyant quartz encountered in shells entirely filled with internal sediment. The internal walls of shells filled with granular quartz are locally covered by dogtooth cement (Fig. 10e).

The cracks, several millimeters wide, which cut through the dyke are filled with mudstone/wackestone or by internal sediment with Fe-oxides, sometimes rich in crushed calcite crystals (Fig. 9a-c). The walls of these cracks are covered with blocky calcite cement or dogtooth cement locally overgrown by syntaxial calcite cement with increased $\mathrm{Fe}$ content (Figs. 9a-c, 11; Table 1).

\section{The Grodzisko Rock}

The Grodzisko Rock, located in the northern slope of the Pradnik River Valley, is composed of microbial-sponge and microbial-Crescentiella massive limestones. In adjacent outcrops, massive limestones contain ammonites indicative of the Bifurcatus zone (Ziółkowski 2007), whereas in the overlying, pelitic, and detrital limestones (wackestonespackstones), fossils typical of the Bimammatum Zone were found (Ziółkowski 2007).

The contact of the neptunian dyke with the massive limestones is sharp. The brownish material infilling the dyke is greatly karstified and disintegrated. The matrix around the brachiopod shells has barely survived. Brachiopods form the rudstone, composed of chaotically arranged but perfectly preserved and usually empty shells (Fig. 7d). The outer surfaces of shells locally show disarticulation (cf. Olóriz et al. 2002). The degree of fragmentation is very low. Sporadically, we observed crushed shells or their fragments. Some shells are filled with coarse crystalline quartz.

\section{Brachiopods from the neptunian dykes}

The brachiopods from MQ, BC, and GR could not be precisely identified due to the exclusively relic-grade preservation of brachial apparatuses. In brachiopod accumulations, shells were occasionally crushed, but most were perfectly preserved. In any case, our brachiopods belong to a monospecific assemblage of rhynchonellids, cf. Lacunosella sp., although forms with smoother shell surfaces are also present. The latter resemble terebratullids but presumably, based on the presence of subtle ridges, are only variants of rhynchonellids. The shells are articulated. Both juvenile and adult forms are present. The abundance in MQ reaches 33 specimens, in the BC 14 specimens, and in GR reaches 18 specimens per $25 \mathrm{~cm}^{2}$. The width of the shells from MQ varies from 5.2 to $30 \mathrm{~mm}$, the length from 5.7 to $27.2 \mathrm{~mm}$, with average values of 15 and $13 \mathrm{~mm}$, respectively; from $\mathrm{BC}$ the width varies from 6 to $30.1 \mathrm{~mm}$, the length from 5.9 to $27.2 \mathrm{~mm}$, with average values of $25 \mathrm{~mm}$ for both, and from GR the width varies from 6 to $30.1 \mathrm{~mm}$, the length from 6.2 to $27.2 \mathrm{~mm}$, with average values of $25 \mathrm{~mm}$ for both.

\section{Analytical results}

\section{General geochemistry}

The floatstone infilling the $\mathrm{BC}$ neptunian dyke is locally highly silicified $\left(\mathrm{SiO}_{2}\right.$ content up to $68.5 \%$, Table 2$)$. In samples rich in $\mathrm{SiO}_{2}$, we observed increased $\mathrm{Ba}$ content (63-110 ppm) whereas silica-free samples contained distinctly less $\mathrm{Ba}$ (9-38 ppm). In silicified samples, Sr content is lower (from 92 to 128 ppm) but varies in silica-free 


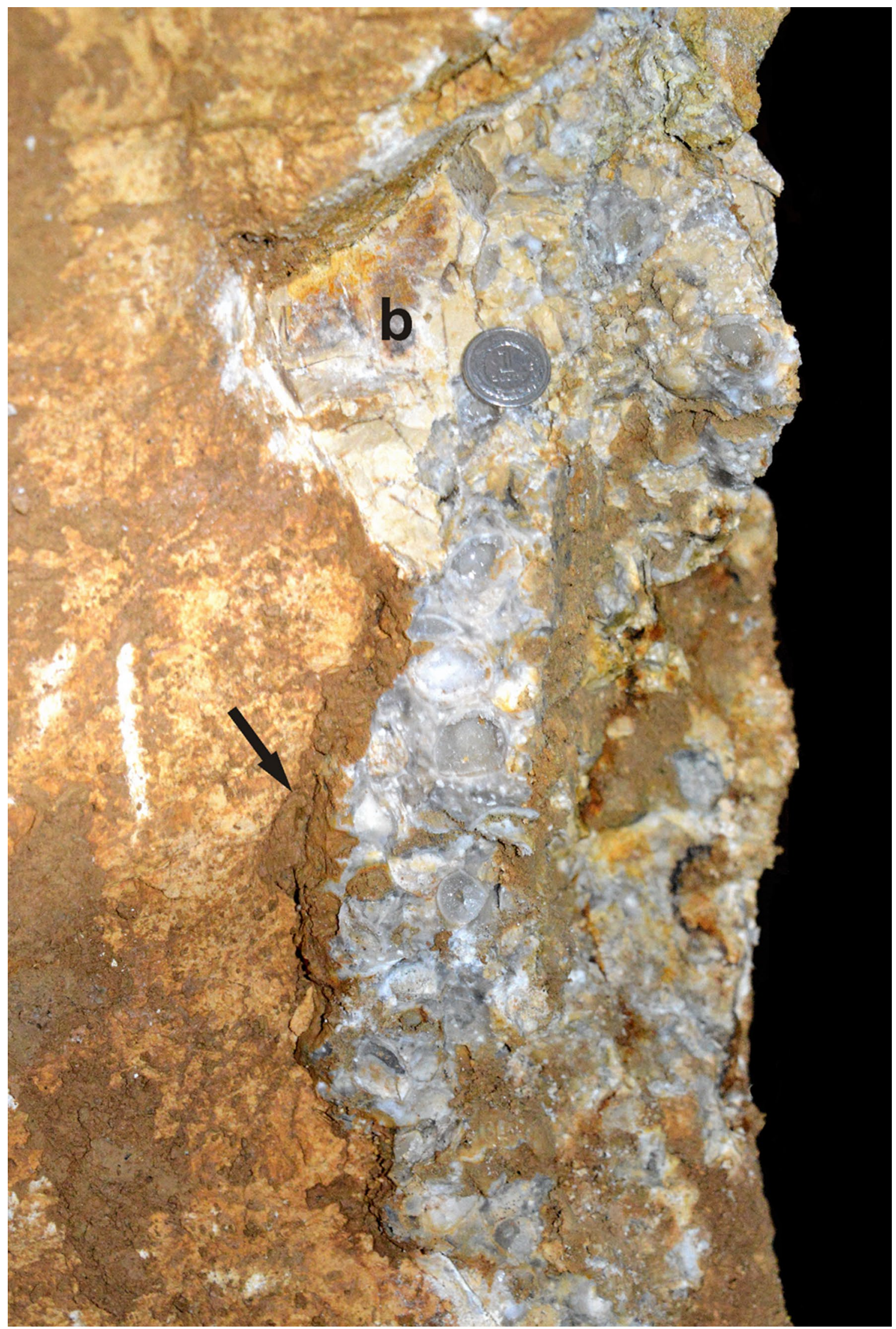


4Fig. 6 Fragment of a neptunian dyke in a corridor wall of the Big Cave in the Kluczwoda Valley. The contact zone of the dyke (on the right) and massive limestone (on the left) is covered with brownish karst sediment (black arrow). To the left of the coin, breccia of massive limestone $(b)$ is exposed

samples from 161 to $181 \mathrm{ppm}$. The floatstone from the MQ neptunian dyke show a chemical composition similar to silica-free fragments of the $\mathrm{BC}$ dyke (Table 2).

\section{Cement geochemistry}

The results of microprobe point analyses of dogtooth calcite cements and syntaxial calcite overgrowth cements collected from fractures cutting through the $\mathrm{BC}$ dyke are listed in Table 1 and shown in Fig. 11. The syntaxial cements indicate increased Fe content (up to $2.090 \mathrm{ppm}$ ), whereas in the dogtooth cements Fe contents do not exceed 80 ppm and are usually below the MPA detection limit. The remaining analyzed elements show no distinct correlations with these two types of cements.

\section{Nd isotope geochemistry}

The results of $\mathrm{Nd}$ isotope studies of the matrix of floatstones from the MQ and BC neptunian dykes show some differences (Table 3). For $9 \mathrm{BC}$ samples, the $\varepsilon_{(T=160 \mathrm{Ma})}$ values change from -8.1 to -6.3 (average value: -7.2 ),
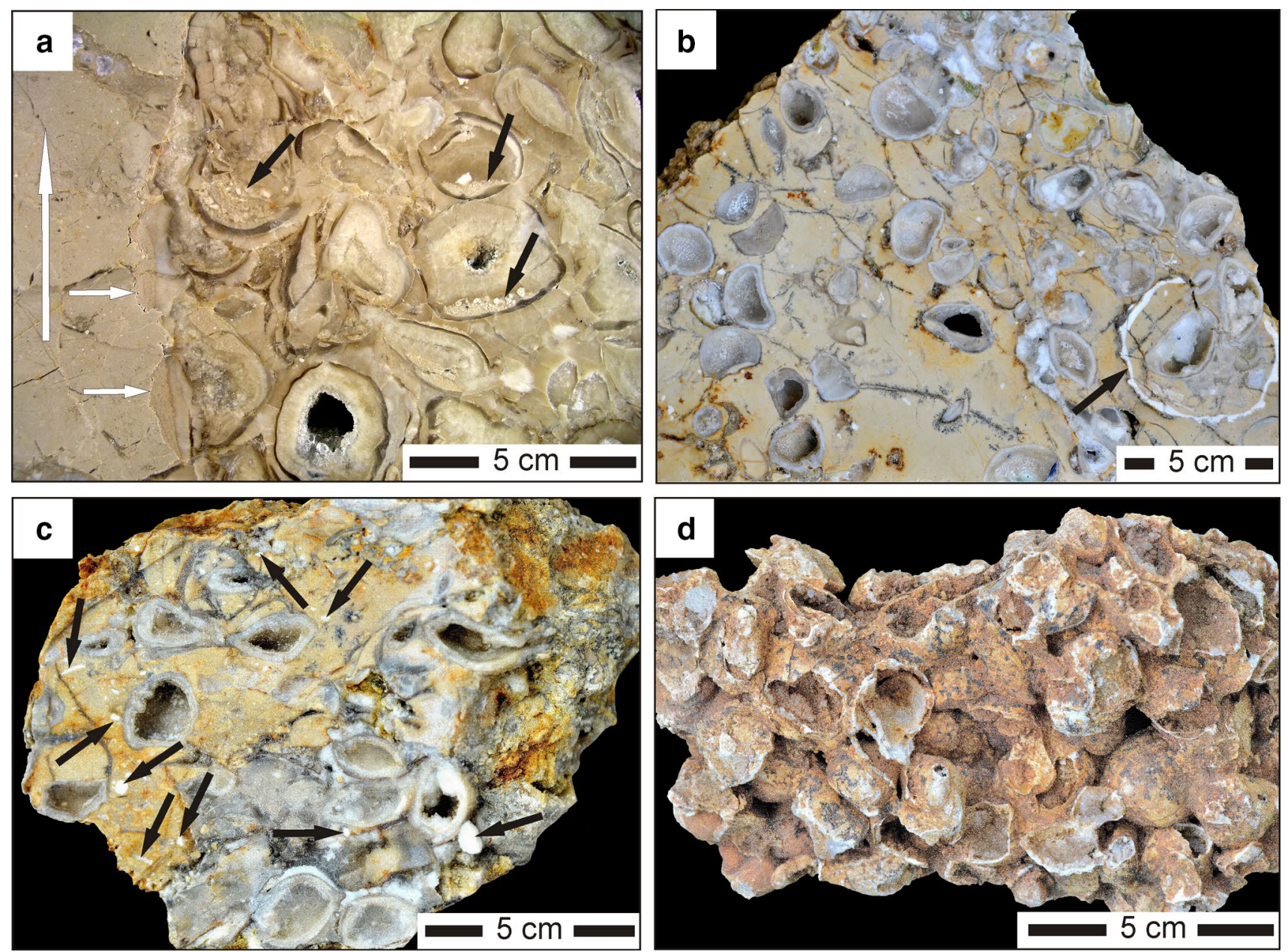

Fig. 7 Infilling of the BC (a-c) and GR (d) neptunian dykes: a contact of the dyke (right) and massive limestone (left). Visible in the contact zone are fragments of vertical laminated stromatolites (white arrows), which were separated from the wall of massive limestone along a short distance due to fault displacement. Brachiopod shells located close to the wall are crushed, whereas those located in the centre are fully preserved. Some shells are geopetally filled with grainstone (black arrows) with numerous echinoderm plates. The top is indicated by big white arrow; $\mathbf{b}$ floatstone with brachiopods and

fragments of echinoderms in the matrix. On the right: a fully preserved echinoid test (arrow). The rock is fractured and the fractures are impregnated with black Mn dendrites and brownish Fe oxides; c floatstone; locally, rudstone with brachiopods. In the matrix, fragments of echinoid tests and spines are visible (arrows). In the lower part of the photograph, brachiopod shells, the cavity between them, and the adjacent matrix are all filled with coarse crystalline quartz; $\mathbf{d}$ empty shells contact each other. The matrix was removed by karstic processes 

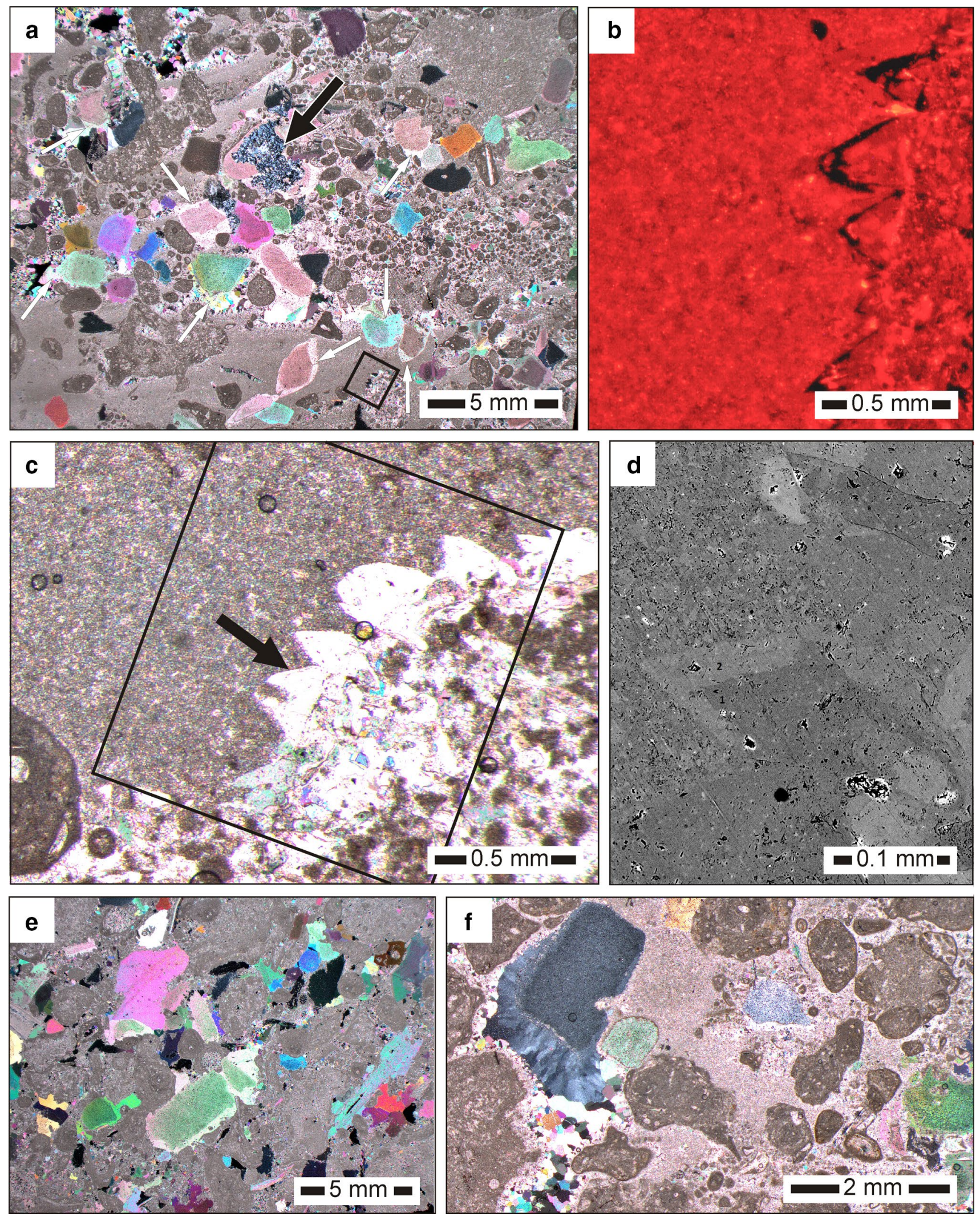
4Fig. 8 Microfacies of the BC neptunian dyke: a floatstone with fragments of echinoderm plates and calcified Hexactinellid sponges, tuberoids, Crescentiella morronensis, bryozoans, benthic foraminifera and microoncoids. Syntaxial calcite cement grows on echinoderm plates (white arrows). Larger cavities are usually interconnected and filled with locally laminated internal sediment of the crystal silt type and with calcite cements. Microgranular quartz (black arrow) occur in the centers of cavities, replacing plates of echinoderms and cements infilling the intergranular spaces. The box marks a fragment shown in Fig. 8b. Crossed nicols; b CL image of dogtooth cement locally covering the bottom of a cavity filled with crystal silt. The outer zones of dogtooth crystals do not show luminescence; c the lower part of a cavity filled with internal sediment of the crystal silt type. On the walls of the cavity, crystals of dogtooth cement are seen (arrow). The box marks a fragment shown in Fig. 8a, b. Parallel nicols; $\mathbf{d}$ BSC image of dogtooth crystal. The bright cement growing on the dark crystal indicates increased Fe content; e floatstone with fragments of echinoids embedded within syntaxial cement with fragments of Crescentiella morronensis, Terebella lapilloides, serpules, bryozoans, and tuberoids. Crossed nicols; $\mathbf{f}$ internal sediment of the crystal silt type (centre) filling interconnected, irregular cavities. Tuberoids and echinoderm plates occur in the internal sediment. An echinoderm plate (upper left) was replaced by quartz together with overgrowing syntaxial calcite. Quartz also replaced granular and blocky calcite cements initially filling a fragment of cavity below the plate, over the internal sediment. Crossed nicols

whereas for two MQ samples the $\varepsilon_{(T=160 \mathrm{Ma})}$ values are -6.9 and -6.8 .

The $T_{2 \mathrm{DM}}$ age for $\mathrm{BC}$ samples varies from 1.46 to $1.61 \mathrm{Ga}$ (average value: $1.54 \mathrm{Ga}$ ), for MQ samples from 1.50 to $1.51 \mathrm{Ga}$ (Table 3). Differences are minor but relevant to the stratigraphic positions of both dykes.

\section{Fluid inclusions}

The fluid inclusions found in quartz crystals are rare and small $(<10 \mu \mathrm{m})$ and filled with the liquid phase, which is an aqueous solution with small gas bubbles. Some small $(<5 \mu \mathrm{m}$ long) inclusions developed gas bubbles only after cooling, i.e. after breakdown of the metastable homogeneous state. Since the formation pressure of quartz crystals should be low and probably close to that of a rather thin seawater column, the actual formation temperature of inclusions does not differ significantly from that determined using homogenization temperatures.

Our inclusions can be divided into two groups. The first includes the earliest inclusions present in the central parts of quartz crystals, which homogenized at $T_{\mathrm{h}}=89-54{ }^{\circ} \mathrm{C}$. These are relatively large (from ca 5 to nearly $10 \mu \mathrm{m}$ ), primary inclusions, i.e. syngenetic with the appropriate zones of studied quartz crystals. Their homogenization temperatures are quite high and variable. Moreover, the same parts of quartz crystals host fluid inclusions of the second group, which are smaller $(<5 \mu \mathrm{m})$ and yield homogenization temperatures $T_{\mathrm{h}}$ of $52-51{ }^{\circ} \mathrm{C}$. In two cases, two or three first-group inclusions shared the same growth zone with the single inclusion of the second group, and each inclusion provided a different homogenization temperature. This would suggest the heterogeneous trapping of the fluid portion, i.e. at least the first group of inclusions were formed through overgrowth of a portion of liquid with a small gas bubble. The gas bubbles may have formed due to a very local pressure decrease or release of gas from the wall rock sediment.

The outer parts of quartz crystals contain fluid inclusions of the second group, usually smaller than those from the central parts and sometimes not as clearly syngenetic with quartz crystallization. Nevertheless, the majority are primary, or most probably primary. Moreover, they display almost constant $T_{\mathrm{h}}$ values, from 52 to $49{ }^{\circ} \mathrm{C}$. Unquestionable evidence was found in the growth zone in the part of a quartz crystals where heterogeneous trapping occurred together with homogeneous: two inclusions of $T_{\mathrm{h}}=51{ }^{\circ} \mathrm{C}$ were identified on two sides of an inclusion which homogenized at $72{ }^{\circ} \mathrm{C}$ (Fig. 12; Table 4). Thus, the two inclusions originated from homogeneous trapping; their $T_{\mathrm{h}}$ values indicate the formation temperature of quartz, whereas the third inclusion formed by heterogeneous trapping homogenized at an incidental temperature.

All the inclusions were filled with diluted solutions (4.9-3.3 wt\% of total salt concentration) with $\mathrm{NaCl}$ and $\mathrm{CaCl}_{2}$ as the main components. Moreover, inclusions of the first group may have included very low admixtures of $\mathrm{KCl}$, too low for accurate quantitative determinations. As well, traces of carbon dioxide or methane were detected in the gas phase of some inclusions. However, it should be remembered that low-concentration components may have been omitted due to the small sizes of the studied inclusions.

\section{Discussion}

\section{Position in the ecosystem and trophic relationships}

In Upper Jurassic microbial-sponge megafacies from the northern margin of the Tethys, both terebratulids and rhynchonellides are more common in Upper Jurassic carbonate buildups than in inter-buildup facies (cf. Wagenplast 1972; Nitzopoulos 1974; Gwinner 1976; Boullier 1993; Grădinaru and Bărbulescu 1994; Sulser and Meyer 1998; Brugger 1999; Helm and Schülke 1999; Helm 2005; Olóriz et al. 2006; Courville et al. 2007; Lazăr et al. 2011). Moreover, brachiopods from carbonate buildups exhibit significant diversity of morphotypes (Helm 2005). In dense populations, decreasing size, asymmetry and even deformations of shells have been observed (Asgaard 1968; Boullier 1993; Brugger 1999; Lazăr et al. 2011).

Lacunosella sp. range from the Middle Jurassic to the Early Cretaceous and are cited as forms typical of the 

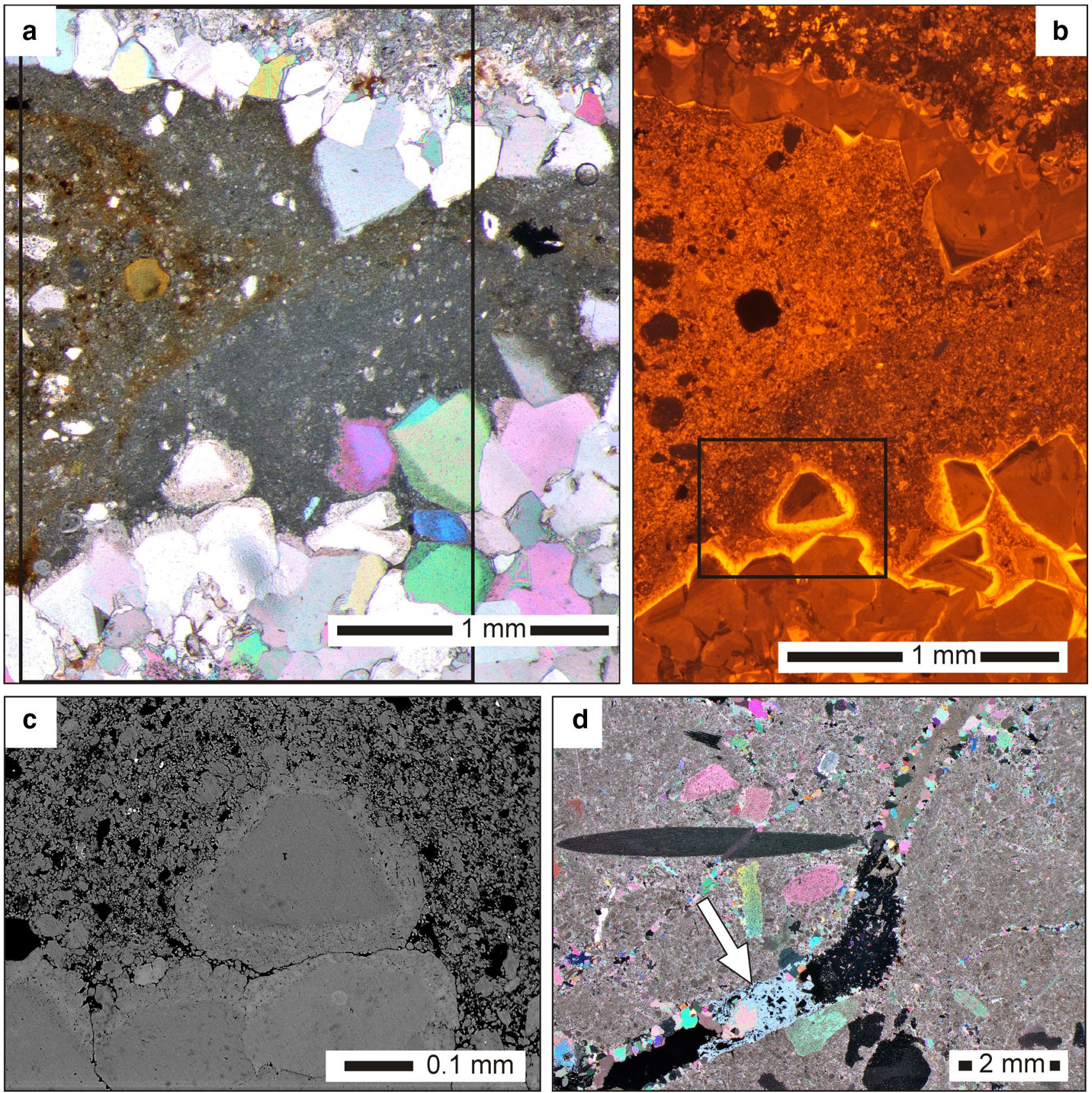

Fig. 9 Infilling of small fractures in the BC neptunian dyke: a a fracture cutting through the dyke, filled with locally ferruginous internal sediment with broken calcite crystals (left). The fracture's walls are covered with dogtooth cement locally overgrown by syntaxial calcite cement of increased Fe content. The box marks the area shown in $\mathbf{b}$. Crossed nicols; $\mathbf{b}$ CL image of cements covering the fracture walls. The dogtooth cement covering the walls is overgrown with syntaxial cement of bright luminescence. The box marks the area illustrated in c; c BSC image of dogtooth cement overgrown by syntaxial calcite cements. Bright crystals of syntaxial calcite cement indicate $\mathrm{Fe}$

northern margin of the Tethys (Sandy 1988). Accumulations of L. cracoviensis in Oxfordian microbial-sponge buildups were described from the Dobrogea region in enrichment; $\mathbf{d}$ irregular fracture with diversified infilling. In the upper part of the photograph, the fracture walls are covered with blocky calcite cement; the interior is filled with mudstone. In the lower part, the fracture is locally filled by quartz with abundant inclusions and relics of blocky calcite cement (arrow). Occurring on the centre-left is an echinoid spine which is broken and displaced along another fine fracture filled with granular calcite cement. In the matrix, echinoderm plates with locally growing syntaxial cement are visible. Crossed nicols

southeastern Romania (Grădinaru and Bărbulescu 1994). However, in that region, L. cracoviensis occurs rather in larger microbial-sponge and microbial buildups, whereas 
L. arolica is typical of small buildups (Herrmann 1996; Lazăr et al. 2011). According to Lazăr et al. (2011), the environments particularly preferred by accumulations of $L$. cracoviensis are the slopes of microbial-sponge and microbial buildups, where some brachiopods might have grown in situ and others might have been relocated down the slope to those sites. L. cracoviensis is regarded as a shallowmarine form and its shells are settled by epifauna, which is related to the presence of distinct ridges (Krawczyński 2008). The discovery of juvenile brachiopods in the shells of adult animals found in sediments filling neptunian dykes indicates that juveniles may have lived inside the living adult brachiopods (cf. Lazăr et al. 2011), that is, may have applied an endosymbiotic life strategy.

Brachiopods have a low metabolic rate, low nutrient demands (Gahr 2005; Abdelhady and Fürsich 2014) and are able to assimilate dissolved substances during times of low influx of particulate food (Steele-Petrovič 1976, 1979). Brachiopod dominance may be enhanced by reduced oxygen levels and a low nutrient supply (Gahr 2005; Tomašových 2006). However, defining the environment in this way does not explain why nearly monospecific accumulations of brachiopod assemblages occur in the studied neptunian dykes.

Although brachiopods are almost unknown from recent active vent sites (Tunnicliffe 1992a, b; Lee et al. 2008), we are of the opinion that the domination of brachiopods in the environment around the neptunian dykes may have resulted from the action of shallow-water hydrothermal vents. Similarly to hydrocarbon seeps, such sites support mass growth of specific fauna, sometimes including brachiopods (Sandy and Campbell 1994; Campbell and Bottjer 1995; Little et al. 1997, 1999, 2004; Van Dover 2000; Peckmann et al. 2007, 2011; Gischler et al. 2003; Lee et al. 2008; Sandy 2010; Bujtor 2011; Sandy et al. 2014; Kiel et al. 2014; Hryniewicz et al. 2015).

The depositional environment of Upper Jurassic microbial-sponge facies in the northern margin of the Tethys occupied variable depths. The upper parts of carbonate buildups grew close to the storm wave base, whereas the inter-buildup zones were located up to $100 \mathrm{~m}$ deeper (Matyszkiewicz 1999; cf. Olóriz et al. 2006). Hence, this environment can be linked to shallow-water hydrothermal vents (Dando 2010). Contrary to their deep-sea counterparts, such vents are characterized by the lack of vent-specific taxa (Tarasov et al. 2005) or by the presence of only one or two non-vent-obligate genera or higher taxa (Dando 2010). In the vicinity of shallow-water hydrothermal vents, not only is seawater temperature locally higher, but venting fluids may also reduce salinity due to the input of ascending meteoric water (Stüben and Glasby 1999; Dando et al. 2000), which implies the development of specific biocenoses. The zones of shallow-water hydrothermal seepage are well known for particularly intensive growth of bacteria and microbial mats (cf. Stanier and Cohen-Bazire 1977; Tunncliffe 1988, 1991, 1992a, b; Taviani 1994; Mounji et al. 1998; Dando et al. 2000; Tarasov et al. 2005; Reolid and Abad 2014), which may have provided nourishment for brachiopods feeding on phytoplankton, bacteria, colloidal and dissolved nutrients (Steele-Petrovič 1976, 1979). According to Little et al. (2004), some Mesozoic brachiopod taxa may have had chemosymbionts as well (cf. Sandy 1995; Campbell and Bottjer 1995; Sandy and Campbell 1994). Moreover, Campbell (2006) states that brachiopods appear to be attracted to vents or seeps, because such sites provide access to high concentrations of bacterioplankton to be filtered from the water column. Brachiopods from neptunian dykes, like all modern brachiopods (cf. Little et al. 2004), were certainly filter feeders, and the water energy must have been sufficient to keep food particles in suspension (cf. Ayoub-Hannaa et al. 2014).

Another, much less common group of organisms found in sediments filling the neptunian dykes is regular and irregular echinoderms. We found fragments of echinoid plates as well as fully preserved specimens (Fig. 7b). In hydrothermal vent or seep environments, echinoderms are rather rare, or absent (Grassle 1985; Desbruyères et al. 2006). In the central part of KCU, echinoids were observed in Upper Oxfordian carbonate buildups, in microbial mats with numerous coproliths, whose origin can also be related to warm hydrothermal seeps (Matyszkiewicz et al. 2006b; Kochman and Matyszkiewicz 2012). The source of nourishment for echinoids may also have been free-living bacteria settled in the neighborhood of fractures or microbial mats flourishing close to seep deposits during the activity of hydrothermal vents or during the final phase of chemoherms in the basin (cf. Gaillard et al. 2011).

\section{The rationale for the occurrence of hydrothermal vents}

The composition of Late Jurassic epicontinental sea waters occupying the southern part of the KCU corresponds to that of recent oceanic waters (Olivier and Boyet 2006; Matyszkiewicz et al. 2012. The isotopic composition of Nd documents global changes in the supply of more radiogenic waters related to hydrothermal activity over a large area (Stille and Fischer 1990; Stille et al. 1996; Frank 2002; Dera et al. 2015) but does not reflect the local, particularly low-temperature action of hydrothermal fluids due to their extremely short residence time $(<1$ year) in the vicinity of hydrothermal vents (Halliday et al. 1992). The primary Ndisotope composition of hydrothermal vents is not derived directly from the water column, but is representative of shallow burial conditions (cf. Jakubowicz et al. 2015).

In a sample of unaltered Upper Oxfordian limestone from the northern part of $\mathrm{KCU}$, the $\varepsilon_{\mathrm{Nd}(T=155 \mathrm{Ma})}$ value is 

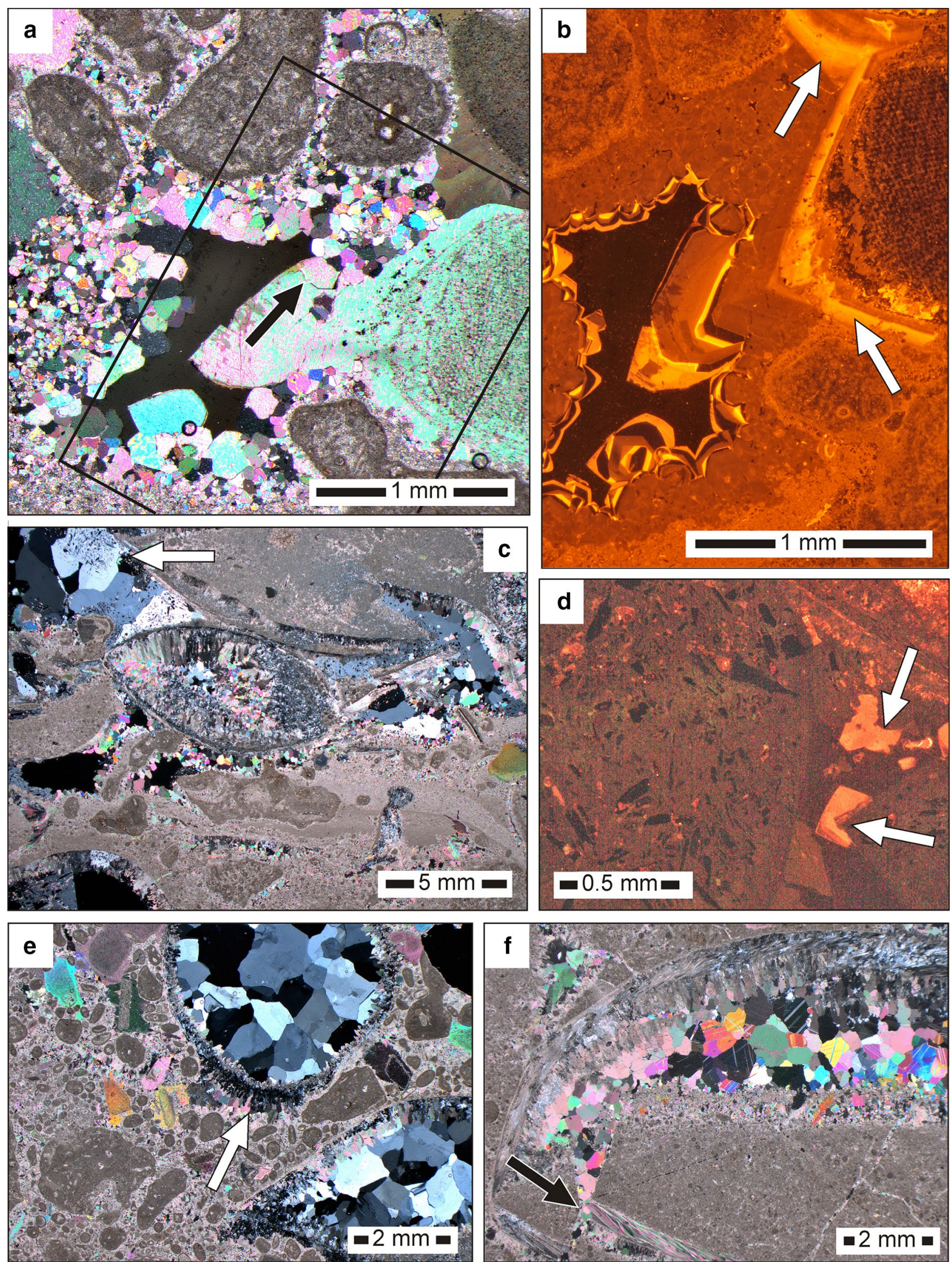
4 Fig. 10 Internal sediments, cements and silicification in the BC neptunian dyke: a infilling of the upper part of cavity with floatstone. Syntaxial calcite cement is observed on echinoid plates (centre right and upper right), grading with optical continuity towards the cavity centre into blocky calcite cement with relics of granular cement (arrow). Surfaces of tuberoids (upper right and lower right) are locally covered with isopachous granular cement, which grades towards the cavity centers into dogtooth cement, followed by granular cement. The box marks the area shown in b. Crossed nicols; $\mathbf{b}$ CL image of several generations of cements infilling a cavity. Early diagenetic, isopachous granular, syntaxial and dogtooth cements show dark-orange luminescence. Granular cement, which overgrows the others, shows dark-red luminescence. Blocky calcite cement of distinct zonal luminescence represents at least two generations of cements: the first developed on syntaxial cement (arrows), whereas the second filled the cavity centre; c floatstone with brachiopod shells. The spaces between shells are filled with laminated internal sediment, carbonate cements, and at least two generations of quartz. Upper left coarse crystalline quartz with numerous fluid inclusions replaces granular and blocky calcite cements, with inclusion-free quartz in optical continuity with the coarse crystalline quartz, occupying the centre of the cavity. The fragment marked with an arrow is shown in $\mathbf{d}$. Crossed nicols; $\mathbf{d}$ CL image of two generations of quartz filling the spaces between brachiopod shells. The older generation (left and centre), which grows directly on cements covering the surface of the shells, contains numerous fluid inclusions. The younger quartz generation (on the right), which fills the cavity centre, comprises inclusion-free crystals with relics of blocky calcite cement in bright luminescent colors (arrows); e floatstone with brachiopod shells, the interiors of which are filled with granular quartz with rare inclusions. The inner walls of the shells are covered with dogtooth cement. Intraclasts, tuberoids, microoncoids, Crescentiella morronensis and echinoderm plates with syntaxial cement are observed in the matrix enclosing the shells. On the outer surface of shell occur gravitative fibrous cement (arrow). Crossed nicols; $\mathbf{f}$ infilling of a brachiopod shell. The lower part of the shell is filled with internal sediment developed as mudstone and, somewhat higher, as micropeloidal packstone. Blocky calcite cement grows immediately over the surface of the internal sediment. The inner surface of the upper part of the shell is covered with bladed calcite cement. Locally (upper right), shell fragments are silicified. The lower part of the shell is broken and displaced together with internal sediment along a fracture (arrow) filled with blocky calcite cement. Crossed nicols

-6.6 (Matyszkiewicz et al. 2015a). This value seems to correspond to the paleogeographic position of the studied fragment of shelf from the northern margin of the Tethys (cf. Sidorczuk et al. 2009). However, the $\varepsilon_{\mathrm{Nd}}$ values found in sediments filling both the neptunian dykes (particularly the $\mathrm{BC}$ ) are less radiogenic and the range of $\varepsilon_{\mathrm{Nd}}$ values is 1.8 (Table 3), which cannot be explained by simple acquisition of $\mathrm{Nd}$ from the water column (cf. Jakubowicz et al. 2015). Hence, we are of the opinion that the diversity of $\varepsilon_{\mathrm{Nd}}$ values in the $\mathrm{BC}$ dyke representing sediment of the same age must be related to the influence of hydrothermal solutions sourced in the continental crust.

Finally, we relate the increased contents of $\mathrm{Ba}$ in sediments filling the neptunian dykes and silicification processes to the activity of hydrothermal solutions (Table 1) presumably caused by the rejuvenation of fault zones in the Cretaceous and, primarily, in the Cenozoic.

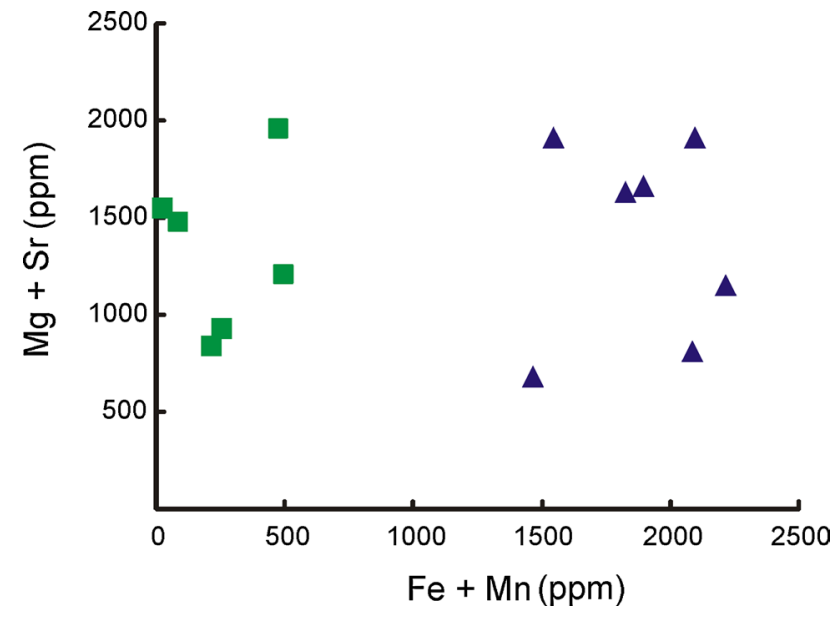

Fig. 11 Cross-plot of $\mathrm{Mg}+\mathrm{Sr}$ and $\mathrm{Fe}+\mathrm{Mn}$ values in dogtooth (green squares) and syntaxial calcite (blue triangles) cements from a tectonic fracture cutting the infilling of the $\mathrm{BC}$ dyke. The points correspond to the values listed in Table 1. Dogtooth and syntaxial calcite cements cluster in two separate fields, indicating two different precipitation environments: meteoric-phreatic and freshwater superficial, respectively

Table 1 Contents of selected elements (in ppm) in dogtooth cements (dtc) and overgrowing syntaxial calcite cements ( $\mathrm{scc}$ )

from the infilling of the fracture cutting the BC dyke (cf. Figs. 9a-c, 11)

\begin{tabular}{|c|c|c|c|c|c|c|}
\hline & $\mathbf{B a}$ & $\mathbf{S i}$ & $\mathbf{F e}$ & $\mathbf{S r}$ & $\mathbf{M n}$ & $\mathbf{M g}$ \\
\hline $\mathrm{dtc}$ & 1080 & 210 & 0 & 780 & 210 & 60 \\
\hline $\mathrm{scc}$ & 0 & 4960 & 1600 & 0 & 290 & 1660 \\
\hline $\mathrm{dtc}$ & 1320 & 870 & 0 & 220 & 20 & 1330 \\
\hline $\mathrm{scc}$ & 370 & 4660 & 1360 & 350 & 460 & 1280 \\
\hline $\mathrm{scc}$ & 0 & 2160 & 1540 & 970 & 0 & 940 \\
\hline $\mathrm{dtc}$ & 0 & 1390 & 0 & 330 & 80 & 1150 \\
\hline $\mathrm{scc}$ & 0 & 1080 & 830 & 0 & 1250 & 810 \\
\hline $\mathrm{dtc}$ & 810 & 1070 & 0 & 910 & 470 & 1050 \\
\hline $\mathrm{scc}$ & 0 & 6980 & 2090 & 760 & 0 & 1150 \\
\hline $\mathrm{dtc}$ & 0 & 880 & 80 & 0 & 170 & 930 \\
\hline $\mathrm{scc}$ & 1050 & 1110 & 1430 & 0 & 780 & 1150 \\
\hline $\mathrm{dtc}$ & 0 & 670 & 30 & 90 & 460 & 1120 \\
\hline $\mathrm{scc}$ & 0 & 1280 & 720 & 270 & 740 & 410 \\
\hline
\end{tabular}

The boxes with bold outlines mark results obtained for cements in direct contact

\section{Conclusions}

\section{The mechanism of formation and infilling of fractures}

Brachiopod-bearing levels appear sometimes in transgressive phases greatly influenced by synsedimentary tectonics (Fürsich et al. 2005; Seyed-Emami et al. 2008; Baeza-Carratalá and Sepehriannasab 2014). Despite some differences in development, it seems that all of the studied neptunian dykes were formed under similar conditions, in the seepage 


\begin{tabular}{|c|c|c|}
\hline 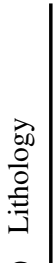 & 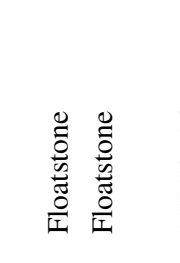 & 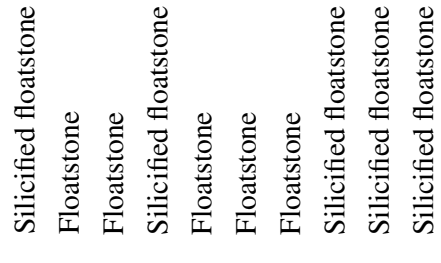 \\
\hline 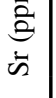 & $\stackrel{8}{g}$ & 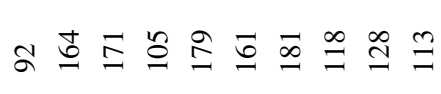 \\
\hline 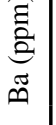 & $a \stackrel{2}{2}$ & $\stackrel{m}{=} \vec{\sim} \hat{b} a=\vec{\sim} \bar{\infty} \dot{\infty}$ \\
\hline 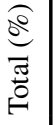 & $\begin{array}{ll}\mathfrak{\alpha} & 0 \\
\infty & \infty \\
\infty & \infty\end{array}$ & 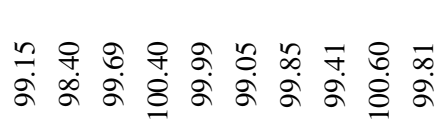 \\
\hline | & $\begin{array}{l}n \\
\stackrel{n}{\infty} \\
\stackrel{m}{m}\end{array}$ & 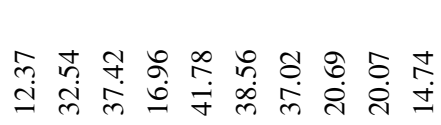 \\
\hline 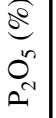 & $\stackrel{0}{0} 0$ & 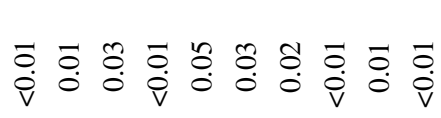 \\
\hline$\overbrace{}^{2}$ & $\overline{8} \overline{8}$ & 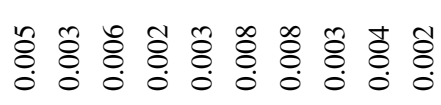 \\
\hline 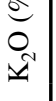 & $\ddot{\ddot{\theta}} \overrightarrow{\ddot{\theta}}$ & 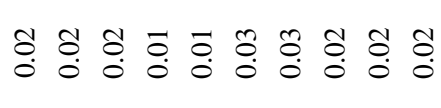 \\
\hline $\begin{array}{l}0 \\
\tilde{\varkappa}^{\prime \prime}\end{array}$ & $\stackrel{0}{0} \stackrel{0}{0}$ & 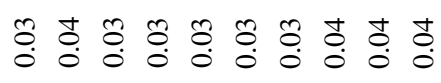 \\
\hline $\begin{array}{l}0 \\
0 \\
0 \\
0\end{array}$ & $\begin{array}{ll}\bar{m} & \stackrel{y}{\sharp} \\
\stackrel{y}{H}\end{array}$ & 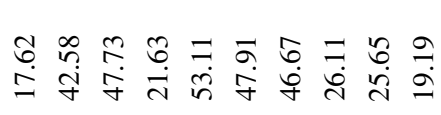 \\
\hline$\sum_{i}^{\infty}$ & กี & 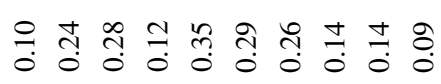 \\
\hline ¿ & $\begin{array}{l}\stackrel{0}{0} \\
\stackrel{0}{0} \\
0\end{array}$ & 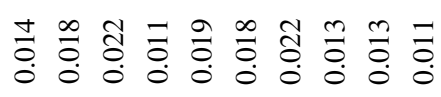 \\
\hline م. & $\stackrel{9}{0}$ & 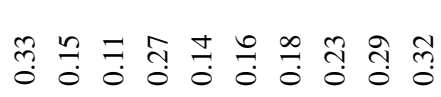 \\
\hline $\begin{array}{c}0^{n} \\
\mathbb{\varangle}\end{array}$ & $\stackrel{n}{0} 0$ & 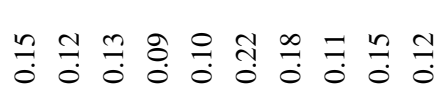 \\
\hline 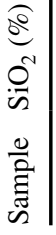 & 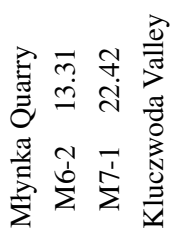 & 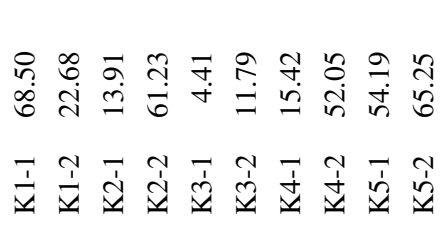 \\
\hline
\end{tabular}

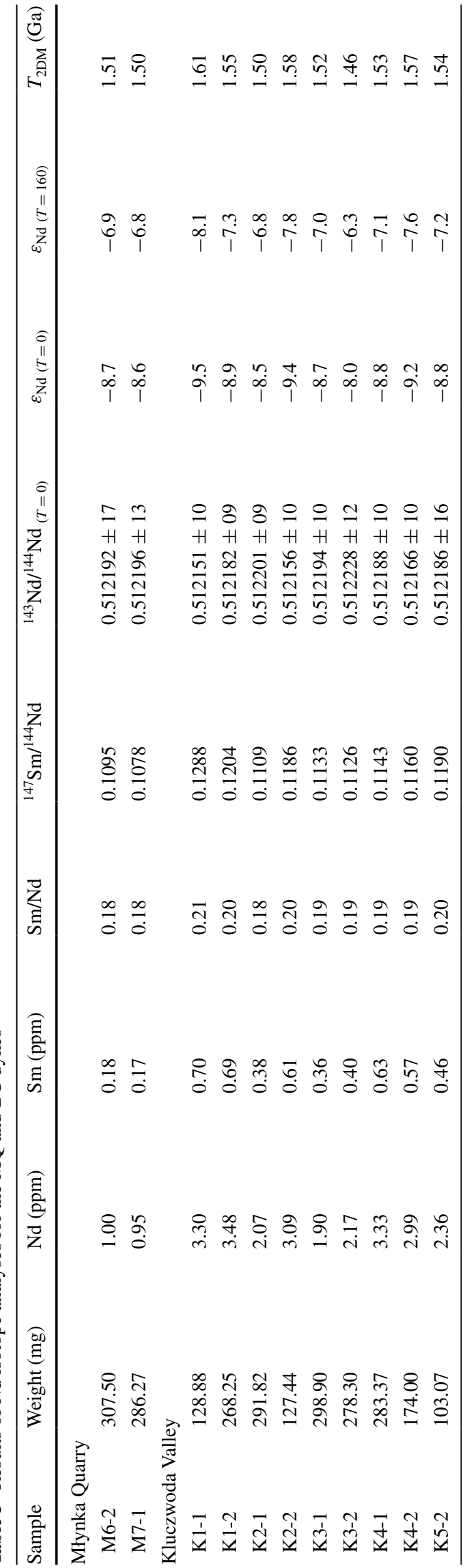




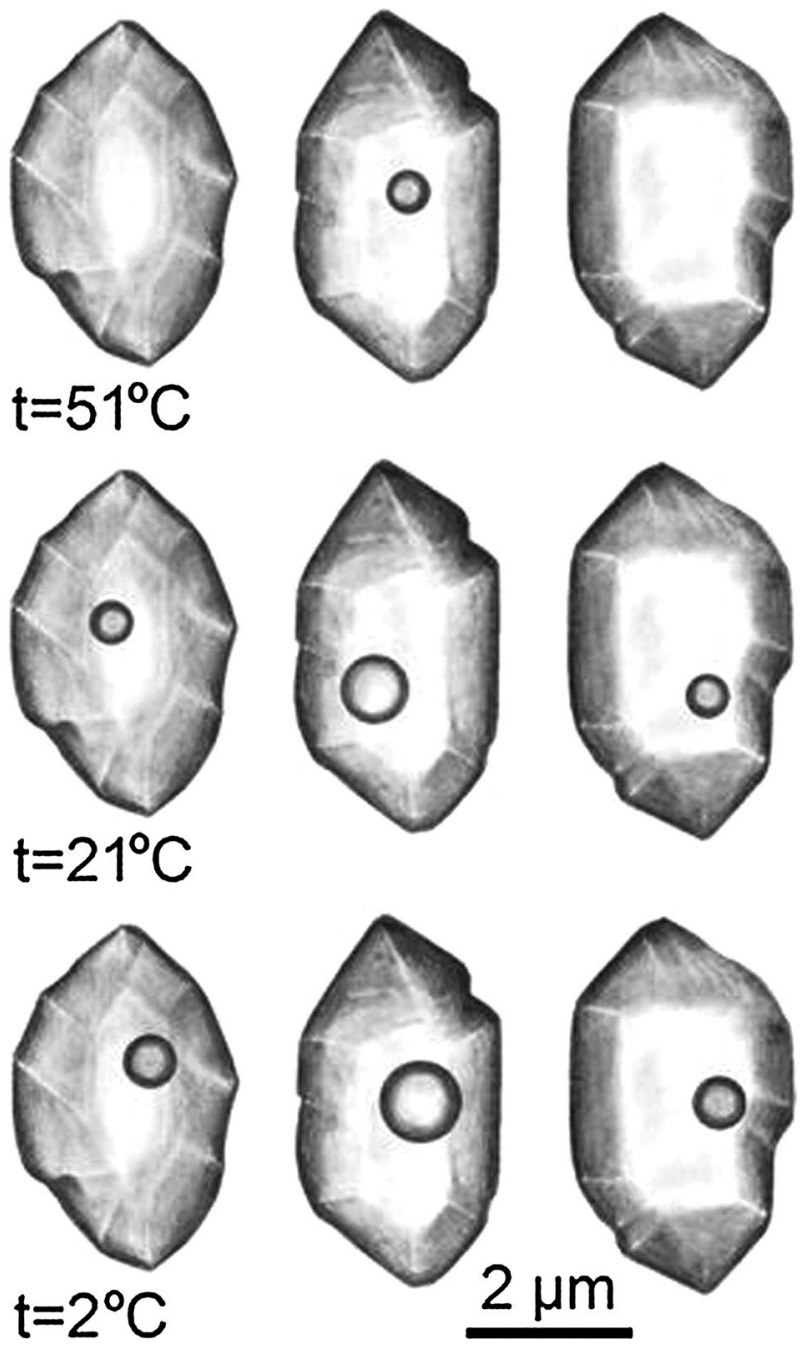

Fig. 12 Three fluid inclusions from the same growth zone in quartz crystals. The larger gas bubble in the central inclusion indicates that trapping of a portion of parent fluid was inhomogeneous; the small gas bubble was overgrown by quartz crystal along with some liquid. Hence, this inclusion shows higher a $T_{\mathrm{h}}\left(72{ }^{\circ} \mathrm{C}\right)$ than the neighboring inclusions formed by homogeneous trapping $\left(T_{\mathrm{h}}=51^{\circ} \mathrm{C}\right)$. Small inclusions occasionally required cooling to nucleate gas bubbles, as shown by inclusions of homogeneous trapping at $2{ }^{\circ} \mathrm{C}$. Drawing by A. Kozłowski

zones of hydrothermal solutions located along the tectonic discontinuities active in the Oxfordian (Fig. 13a-c). The infilling mechanism of both the MQ and the BC dykes was also similar. Unfortunately, the insufficient number of samples from the GR dyke precludes more precise reconstruction of its infilling process, but because the degree of fragmentation of brachiopod shells is very low, this association records probably an autochthonous to parautochthonous community relict (cf. Kidwell 1991).

Stromatolites, which cover the vertical wall of the MQ dyke (Figs. 3, 5a), indicate a temporal hiatus between its opening and infilling (Fig. 13c, d). The lack of cavities filled with internal sediments, along with the similar development of the matrix enclosing the brachiopod shells and the internal sediments filling the shells, indicates that the sediment which filled the fractures was unlithified. Moreover, the presence of echinoderm plates with microbial envelopes (Fig. 5b, e) indicates that their growth upon echinoderm fragments took place under surface conditions, in unconsolidated sediment laid down upon the sea bottom prior to its redeposition into open fractures (Fig. 14). The coexistence of juvenile and adult brachiopods suggests favorable living conditions around the fractures controlled by the abundance of nutrients. In this depositional environment, some brachiopod shells were filled in situ with internal sediments after the death of the organisms and decomposition of their soft tissues. These internal sediments are identical with the deposits enclosing the shells. Moreover, the internal upper surfaces of the shells were covered with early diagenetic, radiaxial fibrous and bladed calcite cements (Fig. 5; cf. Kendall and Tucker 1973; Reinhold and Kaufmann 2010; Richter et al. 2011). Simultaneously, the crusts of isopachous granular cements grew on some tuberoids and bioclasts embedded within the sediment (Fig. 14).

The varying orientations of the geopetal infillings of brachiopod shells indicate their redeposition into open fissures together with unconsolidated sediment covering the sea bottom. Infilling of fractures was triggered by tectonic activity and submarine gravity flow (Fig. 13d), as revealed by the presence of angular clasts of massive limestones in the infilling material (Fig. 3). Deformations of brachiopod shells, i.e. their 'stretching' along the fracture walls, document the stage of vertical displacement of tectonic blocks along fractures filled with still-unlithified sediment (Fig. 13e).

The infilling of the $\mathrm{BC}$ neptunian dykes, similar to that of the MQ, was preceded by a temporal hiatus. The preserved fragments of stromatolites growing on the vertical wall of the fracture cutting the massive limestone (Fig. 7a) constitute evidence that the fracture remained empty for some time. However, the infilling of the BC dyke differs from that of the MQ dyke in terms of: (1) the widespread development of syntaxial calcite cement on echinoderm plates (Figs. 8a, e, 9d, 10e) and the simultaneous absence of microbial envelopes; (2) the sporadic development of typical early diagenetic radiaxial fibrous and bladed calcite cements within both the brachiopod shells and the enclosing sediment; and (3) the presence of numerous cavities filled with internal sediment (Figs. 8a, c, f, 10c). These differences seem to reflect a shorter period of influence of seawater and microorganisms living on the sea bottom on sediment and the partial lithification of the sediment prior to redeposition into the fractures. 
Table 4 Fluid inclusion data

\begin{tabular}{|c|c|c|c|c|c|c|}
\hline Lp. & $T_{\mathrm{h}}\left({ }^{\circ} \mathrm{C}\right)$ & $\mathrm{S}(\mathrm{wt} \%)$ & $\mathrm{NaCl}(\mathrm{wt} \%)$ & $\mathrm{KCl}(\mathrm{wt} \%)$ & $\mathrm{CaCl}_{2}(\mathrm{wt} \%)$ & $\mathrm{CO}_{2}$ or $\mathrm{CH}_{4}$ \\
\hline \multicolumn{7}{|c|}{ Preparation K2-2 } \\
\hline 1 & 87 & 4.7 & 2.0 & $\sim 0.3$ & 2.4 & - \\
\hline 2 & 82 & 4.9 & 2.2 & $\sim 0.5$ & 2.2 & tr. $\mathrm{CO}_{2}$ \\
\hline 3 & 74 & 3.7 & 3.0 & - & 0.7 & Low $\mathrm{CO}_{2}$ \\
\hline 4 & 70 & 3.7 & 2.8 & - & 0.9 & Low $\mathrm{CO}_{2}$ \\
\hline 5 & 58 & 4.1 & 3.1 & - & 1.0 & Low $\mathrm{CH}_{4}$ \\
\hline 6 & 52 & 4.1 & 3.1 & - & 1.0 & Low $\mathrm{CH}_{4}$ \\
\hline 7 & 52 & 4.0 & 3.0 & - & 1.0 & - \\
\hline 8 & 51 & 4.1 & 3.1 & - & 1.0 & Low $\mathrm{CH}_{4}$ \\
\hline 9 & 51 & 4.3 & 3.0 & - & 1.3 & - \\
\hline 10 & 51 & 4.5 & 3.1 & - & 1.4 & - \\
\hline 11 & 49 & 4.0 & 3.0 & - & 1.0 & Low $\mathrm{CH}_{4}$ \\
\hline 12 & 49 & 4.5 & 3.2 & - & 1.3 & - \\
\hline 13 & 49 & 4.2 & 3.2 & - & 1.0 & - \\
\hline 14 & 49 & 4.2 & 3.1 & - & 1.1 & - \\
\hline \multicolumn{7}{|c|}{ Preparation K4-2 } \\
\hline 15 & 89 & 4.9 & 2.1 & $\sim 0.5$ & 2.3 & tr. $\mathrm{CO}_{2}$ \\
\hline 16 & 88 & 4.9 & 2.4 & $\sim 0.3$ & 2.2 & - \\
\hline 17 & 85 & 4.5 & 2.5 & $\sim 0.3$ & 2.0 & - \\
\hline 18 & 83 & 4.6 & 2.4 & $\sim 0.3$ & 1.9 & tr. $\mathrm{CO}_{2}$ \\
\hline 19 & 77 & 3.3 & 2.5 & - & 0.8 & Low $\mathrm{CO}_{2}$ \\
\hline 20 & 76 & 3.3 & 2.3 & - & 1.0 & Low $\mathrm{CO}_{2}$ \\
\hline 21 & 72 & 3.6 & 2.5 & - & 1.1 & tr. $\mathrm{CO}_{2}$ \\
\hline 22 & 54 & 4.0 & 3.6 & - & 1.2 & Low $\mathrm{CH}_{4}$ \\
\hline 23 & 51 & 4.2 & 3.2 & - & 1.0 & Low $\mathrm{CH}_{4}$ \\
\hline 24 & 51 & 4.1 & 3.0 & - & 1.1 & - \\
\hline 25 & 51 & 3.9 & 2.9 & - & 1.0 & - \\
\hline 26 & 51 & 4.3 & 3.1 & - & 1.2 & - \\
\hline 27 & 51 & 3.9 & 2.0 & - & 1.0 & Low $\mathrm{CH}_{4}$ \\
\hline 28 & 50 & 3.9 & 3.0 & - & 0.9 & - \\
\hline 29 & 50 & 4.0 & 3.1 & - & 0.9 & - \\
\hline 30 & 50 & 3.8 & 2.8 & - & 1.0 & - \\
\hline 31 & 49 & 4.2 & 3.0 & - & 1.2 & - \\
\hline 32 & 49 & 3.9 & 3.0 & - & 0.9 & - \\
\hline 33 & 49 & 4.0 & 2.8 & - & 1.2 & - \\
\hline 34 & 49 & 3.8 & 3.0 & - & 0.8 & - \\
\hline \multicolumn{7}{|c|}{ Preparation K5-2 } \\
\hline 51 & 84 & 5.0 & 2.2 & $\sim 0.5$ & 2.3 & - \\
\hline 36 & 81 & 4.8 & 2.0 & $\sim 0.5$ & 2.3 & tr. $\mathrm{CO}_{2}$ \\
\hline 37 & 75 & 3.6 & 2.9 & - & 0.7 & Low $\mathrm{CO}_{2}$ \\
\hline 38 & 72 & 3.5 & 2.5 & - & 1.0 & Low $\mathrm{CO}_{2}$ \\
\hline 39 & 71 & 3.6 & 2.5 & - & 1.1 & Low $\mathrm{CO}_{2}$ \\
\hline 40 & 52 & 4.4 & 3.3 & - & 1.1 & Low $\mathrm{CH}_{4}$ \\
\hline 41 & 52 & 4.2 & 3.0 & - & 1.2 & - \\
\hline 42 & 51 & 4.4 & 3.3 & - & 1.1 & Low $\mathrm{CH}_{4}$ \\
\hline 43 & 51 & 4.0 & 2.8 & - & 1.2 & - \\
\hline 44 & 51 & 4.2 & 3.0 & - & 1.2 & - \\
\hline 45 & 50 & 4.1 & 3.0 & - & 1.1 & Low $\mathrm{CH}_{4}$ \\
\hline 46 & 50 & 4.0 & 3.0 & - & 1.0 & - \\
\hline 47 & 50 & 3.8 & 2.9 & - & 0.9 & - \\
\hline
\end{tabular}


Table 4 continued

\begin{tabular}{cllllll}
\hline Lp. & $T_{\mathrm{h}}\left({ }^{\circ} \mathrm{C}\right)$ & $\mathrm{S}(\mathrm{wt} \%)$ & $\mathrm{NaCl}(\mathrm{wt} \%)$ & $\mathrm{KCl}(\mathrm{wt} \%)$ & $\mathrm{CaCl}_{2}(\mathrm{wt} \%)$ & $\mathrm{CO}_{2} \mathrm{or} \mathrm{CH}_{4}$ \\
\hline 48 & 49 & 4.1 & 3.3 & - & 0.8 & ${\mathrm{Low} \mathrm{CH}_{4}}$ \\
49 & 49 & 3.9 & 3.0 & - & 0.9 & - \\
50 & 49 & 4.1 & 3.1 & - & 1.0 & - \\
51 & 49 & 4.2 & 3.1 & - & 1.1 & - \\
52 & 49 & 3.9 & 3.0 & - & 0.9 & - \\
\hline
\end{tabular}

Dashes indicate content below detection limits

$T_{\mathrm{h}}$ homogenization temperature, $S$ total salinity, $t r$ trace

The partial lithification of the sediment is also indicated by the widespread development of syntaxial calcite cements on fragments of echinoderms as well as by the presence of numerous cavities entirely or partly filled with internal sediment (Fig. 14). Crystallization of syntaxial calcite cement was possible due to: (1) the lack of significant activity by microorganisms which did not produce microbial envelopes over the fragments of echinoderms contained in sediment redeposited into the fractures; (2) the presence of empty spaces in the sediment redeposited into the fractures (cf. Longman 1980); and (3) the influx of ascending warm fresh waters (cf. Waldken and Berry 1984; James and Choquette 1984) from the deeper part of the fractures.

After redeposition of sediment into the fractures, the successive stages of diagenesis proceeded, as revealed by the crystallization of dogtooth cement (Fig. 8e, f) in a marine phreatic environment (cf. Reinhold 1999). Numerous cavities present in the partly lithified sediment which abruptly invaded the fractures were gradually infilled with internal sediment that trickled down into the fissure system (cf. Wall and Jenkyns 2004). The infilling of fractures was presumably driven by slow currents, which are indicated by locally preserved, horizontal lamination of internal sediment infilling the cavities (Fig. 10c; cf. Winterer et al. 1991; Winterer and Sarti 1994; Łuczyński 2001; Wall and Jenkyns 2004). Such lamination forms during the horizontal flow of water currents in the fissure and the simultaneous influx of material from above. The deposition rate of these sediments was low, as indicated by the dogtooth cement covering the edges of small cavities (Figs. 8a-d, 9a-c; cf. Wall and Jenkyns 2004). This is the second generation of cements growing locally on the walls of small cavities and fractures within the sediment and on radiaxial fibrous and bladed cements sporadically covering the internal surfaces of brachiopod shells (Fig. 14).

At the end of the Late Jurassic took place a subaerial exposure of the deposits. In meteoric vadose environment developed gravitative fibrous cements. Subsequent Early Cretaceous tectonic activity (cf. Matyszkiewicz et al. 2015a) was related to the action of hydrothermal solutions, which migrated along the rejuvenated fault zone (cf. Matyszkiewicz et al. 2015a). It was connected with crystallization of dogtooth cement in meteoric-phreatic environment (cf. Reinhold 1999) and probably with local silicification of sediment infilling the fractures (Figs. 8e, f, 14). In the first silicification stage, quartz with copious fluid inclusion crystallized in fine fractures and on the surfaces of cavity walls, replacing carbonate cements (Fig. 10c, d).

During the burial diagenesis, both the granular and the blocky calcite cements crystallized in some still-empty brachiopod shells (cf. James and Choquette 1984). These cements entirely filled or covered the walls of fine fractures resulting from tectonic displacements within the lithified sediments (Fig. 14).

In the Cenozoic, the sediments infilling the neptunian dykes became conduits for the circulation of karst waters migrating along the rejuvenated fault zones. Cracks, small cavities and fractures developed in the matrix; along these, minor displacements occurred. In our opinion, karst processes are responsible for the crystallization of $\mathrm{Fe}$ enriched syntaxial calcite cement, which overgrew the dogtooth cement covering the surfaces of fractures (Table 1; Figs. 9a-c, 11, 14). This cement presumably precipitated from interstitial superficial waters (cf. Jiménez de Cisneros et al. 1990, 1991). Tectonic fractures in which cements did not crystallize were then filled with ferruginous internal sediment (Fig. 9a).

The crystallization of quartz in cavities and brachiopod shells which were not entirely filled with internal sediments proceeded in the first stage of silicification. We interpret second stage of silicification as an effect of the invasion of hydrothermal solutions triggered by episodes of tectonic activity in the Cenozoic (Fig. 14), during which silica-enriched hydrothermal solutions migrated along the reactivated faults (Gołębiowska et al. 2010; Kochman and Matyszkiewicz 2012; Matyszkiewicz et al. 2015a). In the second stage, inclusion-free quartz crystallized in the still-empty centers of cavities and in the interiors of brachiopod shells (Figs. 8f, 10c-e). Unfortunately, it is not clear which silicification stage is responsible for the crystallization of microgranular and microflamboyant quartz (Fig. 8a).

Poor preservation of the GR neptunian dyke precludes more extensive interpretation of its infilling mechanism. 

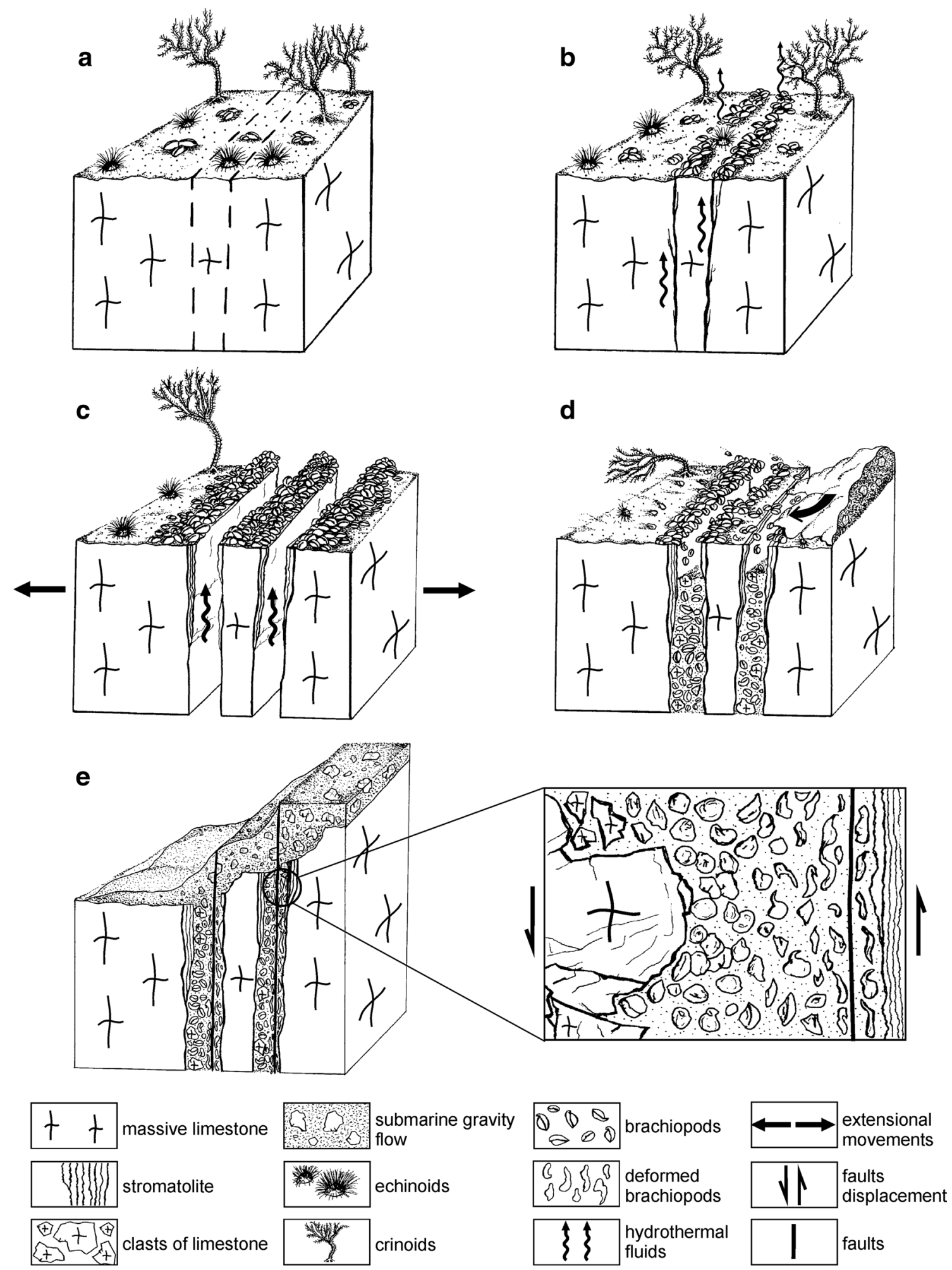
nations in the text). Drawing by P. Kłapyta 


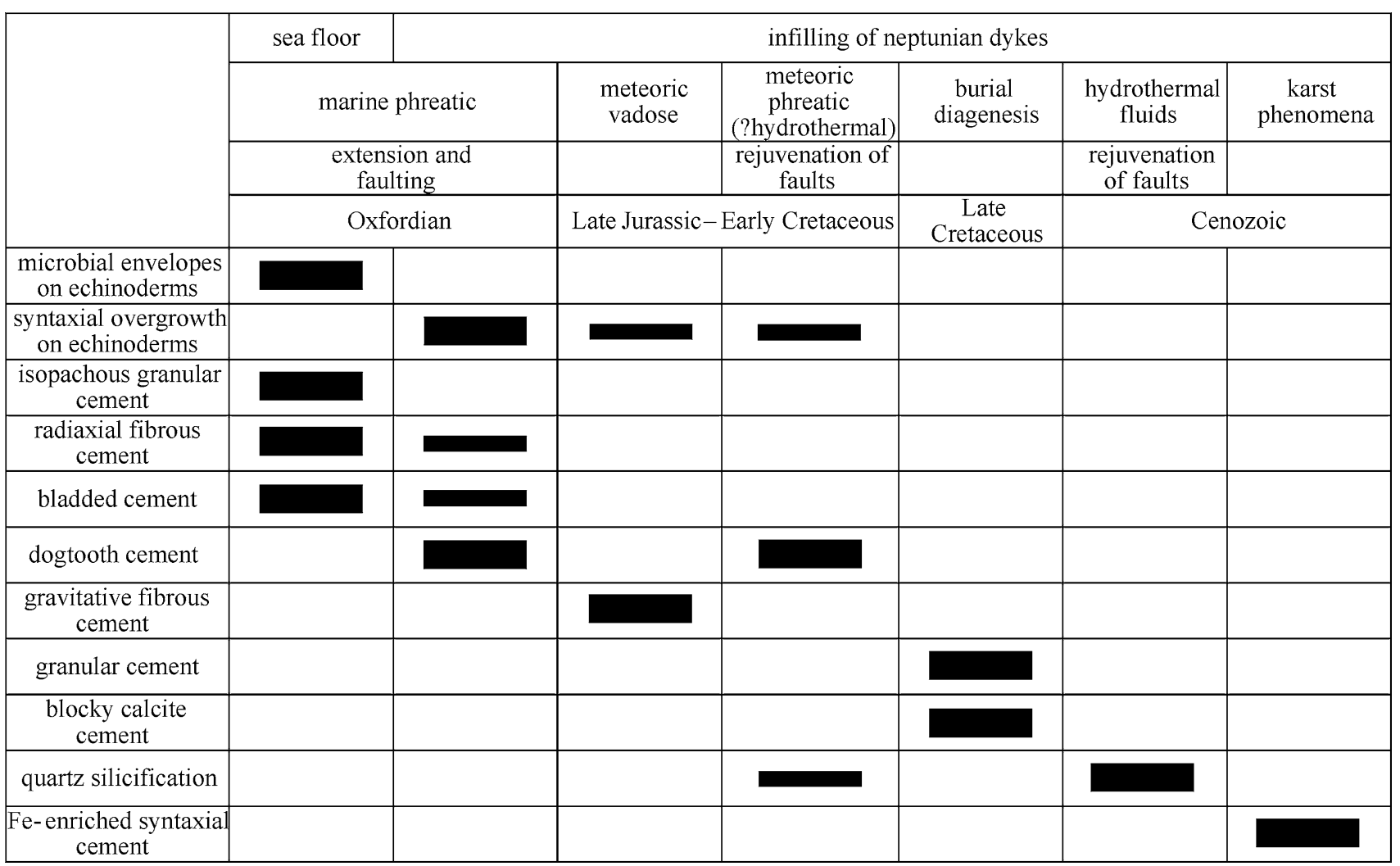

Fig. 14 Relative timing of diagenetic and tectonic events

However, the complete state of the brachiopod shells and the absence of sorting suggest (Fig. 7d) that their relocation into open fractures was abrupt, perhaps involving living animals. The presence of coarse crystalline quartz indicates that fractures filled with brachiopods operated as conduits not only for karst waters but also for hydrothermal solutions.

\section{Structural setting and paleogeographical context}

Undoubtedly, processes active in the Late Jurassic, such as the opening of fractures on the sea bottom and the faulting and redeposition of sediments by submarine gravity flows, were related to tectonic activity in an extensional stress field generated by transregional factors. The opening of both the Northern Atlantic and Tethys Oceans resulted in the Late Jurassic Pan-European stress-field reorganization, which also included the passive, northern margin of the Tethys (Ziegler 1990; Allenbach 2001, 2002; Nieto et al. 2012) together with the recent KCU. In the same period, Paleozoic faults were also rejuvenated, which gave rise to pulses of subsidence and localization of Late Jurassic depocenters over the Late Paleozoic tectonic grabens (Rioult et al. 1991; Færseth 1996; Pittet and Strasser 1998; de Wet 1998; Allenbach 2001, 2002; Wetzel et al. 2003; Krajewski et al. 2014, 2016). These processes continued in the Cretaceous and Neogene.

The recent geological structure of the southern part of $\mathrm{KCU}$ is mostly the effect of Neogene tectonic deformations that occurred when the KCU area was cut by numerous faults, generating a horst and graben system due to the load from overthrusting Carpathian nappes (Dżułyński 1953; Gradziński 1972). The presence of Oxfordian neptunian dykes along with gravity-flow deposits and synsedimentary faults indicates that at least a portion of these horsts and grabens already existed in the Late Jurassic (Matyszkiewicz 1996; Matyszkiewicz et al. 2007; Matyja and Ziółkowski 2014) and were subsequently subject to multiple reactivation, most recently during the Alpine movements. The strike of at least a portion of the faults bordering the Krzeszowice Graben follows the main fault zones in the Paleozoic basement. This is particularly clear in the eastern part of the Krzeszowice Graben, where its northern border corresponds to the course of the KLFZ (Fig. 1; cf. Buła and Habryn 2011; Habryn et al. 2014). It is interesting that the BC neptunian dyke is located over this zone and is characterized by a roughly similar azimuth. The Late Jurassic activity of faults framing the Krzeszowice Graben is indicated by: (1) the gravity flow deposits described from its southern and northern margins (Matyszkiewicz 
1993, 1996); (2) the distinct differences in the development of Upper Jurassic facies at the bottom and in the northern margin of the graben (Ziółkowski 2007; Matyja and Ziółkowski 2014); and (3) the pattern of the MQ neptunian dyke parallel to the local, NW-SE-trending azimuth of the graben margin (Gradziński 2009). Hence, the fault zones bordering the Krzeszowice Graben, rejuvenated in the Neogene (Fig. 1), were formed in the Late Jurassic or even earlier, e.g., in the Late Callovian (Matyja and Ziółkowski 2014), Early Permian (Habryn et al. 2014), or even the Carboniferous (Nawrocki et al. 2008).

Acknowledgments Sincere thanks are due to Mr. Remigiusz Molenda and Mr. Andrzej Górny, who kindly provided a portion of the BC and MQ samples, and to Mr. Mariusz Hoffmann for information on the attitude of the MQ neptunian dyke. The discussion and remarks of Professors Zdzisław Bełka and Andrzej Kaim are very much appreciated, as is the kind assistance of Prof. Michał Zaton in the identification of brachiopods. We are also indebted to the Maciej Kamiński Stonework in Oświęcim for cutting and polishing our large samples from the MQ site. We benefited greatly from comments and suggestions of Matias Reolid and Roman Koch. The project was funded by the National Science Centre on the basis of contract no. DEC-2011/03/B/ST10/06327 and by a statutory grant from the AGH University of Science and Technology.

Open Access This article is distributed under the terms of the Creative Commons Attribution 4.0 International License (http://creativecommons.org/licenses/by/4.0/), which permits unrestricted use, distribution, and reproduction in any medium, provided you give appropriate credit to the original author(s) and the source, provide a link to the Creative Commons license, and indicate if changes were made.

\section{References}

Abdelhady AA, Fürsich FT (2014) Macroinvertebrate palaeo-communities from the Jurassic succession of Gebel Maghara (Sinai, Egypt). J Afr Earth Sci 97:173-193

Allenbach RP (2001) Synsedimentary tectonics in an epicontinental sea: a new interpretation of the Oxfordian basin of northern Switzerland. Eclogae Geol Helv 94:265-287

Allenbach RP (2002) The ups and downs of 'Tectonic Quiescence'recognizing differential subsidence in the epicontinental sea in the Oxfordian in the Swiss Jura Mountains. Sediment Geol 150:323-342

Asgaard U (1968) Brachipod palaeoecology in Middle Danian limestones at Fakse, Denmark. Lethaia 1:103-121

Ayoub-Hannaa W, Radulović BV, Radulović VJ, Fürsich FT, Vasić N (2014) Brachiopods and echinoids from the lower Cenomanian of Koraćica (Kosmaj Mountain, central Serbia). Cretac Res 51:121-147

Baeza-Carratalá JF, Sepehriannasab B (2014) Early Jurassic (latest Toarcian) brachiopods from the northeastern margin of the Western Tethys (Central Iran) and their paleobiogeographical significance. Geobios 47:3-17

Barski M (2012) Dinoflagellate cysts from neptunian dykes in the Middle Jurassic of Poland-a stratigraphical approach. Rev Palaeobot Palyno 169:38-47

Boullier A (1993) Intérêt des Brachiopodes jurassiques en paléobathymétrie. A Geol Aube 15:15-24
Brugger FH (1999) Ökomorphologische Variationen oberjurassischer Brachiopodenassoziationen Suddeutschlands. Berliner Geowiss Abh E29:1-111

Bujtor L (2011) The Early Valanginian ammonite, brachiopod and crustacean fauna of the Mecsek Mts. and its relationships with the embryonic shallow water hydrothermal vent at Zengővárkony (Mecsek Mts., South Hungary). Cretac Res 32:565-574

Buła Z, Habryn R (2011) Precambrian and Palaeozoic basement of the Carpathian foredeep and the adjacent Outer Carpathians (SE Poland and western Ukraine). Ann Soc Geol Polon 81:221-239

Burzewski W (1969) Les conditions structurales du Jurassique de la region d'Olkusz et de Wolbrom comme bordiers pour les gisements petrolifes du Bassin de Nida. Prace Geol PAN 61:3-91 (in Polish with French summary)

Campbell KA (2006) Hydrocarbon seep and hydrothermal vent paleoenvironments and paleontology: past developments and future research directions. Palaeogeogr Palaeoclimatol Palaeoecol 232:362-407

Campbell KA, Bottjer DJ (1995) Brachiopods and chemosymbiotic bivalves in Phanerozoic hydrothermal vent and cold seep environments. Geology 23:321-324

Courville P, Crônier C, Collin PY, Blosse C, Lorin S (2007) Intérêts environnemental et chronologique des bioaccumulations à brachiopodes. Exemple de l'Oxfordien supérieur (Jurassique supérieur) du Bassin parisien (France). C R Palevol 6:87-101

Crawford ML (1981) Phase equilibria in aqueous fluid inclusions. In: Hollister LS, Crawford ML (eds) Fluid inclusions: applications to petrology. Mineralogical Association of Canada, Short Course Handbook, vol 6, pp 75-100

Črne AE, Šmuc A, Skaberne D (2007) Jurassic neptunian dikes at Mt Mangart (Julian Alps, NW Slovenia). Facies 53:249-265

Dando PR (2010) Biological communities at marine shallow-water vent and deep sites. In: Kiel S (ed) The vent and seep biotafrom microbes to ecosystems: topics in geobiology, vol 33. Springer, Heidelberg, pp 333-378

Dando PR, Aliani S, Arab H, Bianchi CN, Brehmer M, Cocito S et al (2000) Hydrothermal studies in the Aegean Sea. Phys Chem Earth 25:1-8

de Wet CB (1998) Deciphering the sedimentological expression of tectonics, eustasy and climate: a basinwide study of the Corallian Formation, southern England. J Sediment Res 68:653-667

Dera G, Prunier J, Smith PL, Haggart JW, Popov E, Guzhov A et al (2015) Nd isotope constraints on ocean circulation, paleoclimate, and continental drainage during the Jurassic breakup of Pangea. Gondwana Res 27:1599-1615

Desbruyères D, Segonzac M, Bright M (2006) Handbook of deep-sea hydrothermal vent fauna. Landesmuseen, Linz

Dong G, Morrison G, Jaireth S (1995) Quartz texture in epithermal veins, Queensland-classification, origin and implication. Econ Geol 90:1841-1856

Dżułyński S (1953) Tektonika południowej części Wyżyny Krakowskiej. Acta Geol Pol 3:325-440 (in Polish)

Færseth RB (1996) Interaction of Permo-Triassic and Jurassic extensional fault-blocks during the development of the northern North Sea. J Geol Soc 153:931-944

Flügel E (2004) Microfacies of carbonate rocks, analysis, interpretation and application. Springer, Berlin

Frank M (2002) Radiogenic isotopes: tracers of past ocean circulation and erosional input. Rev Geophys 40:1-38

Fürsich FT, Wilmsen M, Seyed-Emami K, Majidifard MR (2005) The upper Shemshak Formation (Toarcian-Aalenian) of the Eastern Alborz (Iran): biota and palaeoenvironments during a transgressive-regressive cycle. Facies 51:365-384

Gahr ME (2005) Response of Lower Toarcian (Lower Jurassic) macrobenthos of the Iberian Peninsula to sea level changes and mass extinction. J Iber Geol 31:197-215 
Gaillard C, Néraudeau D, Thierry J (2011) Titohonia oxfordiana, a new Jurassic irregular echinoid associated with Jurassic seep deposits in south-east France. Palaeontology 54:735-752

Gischler E, Sandy MR, Peckmann J (2003) Ibergirhyncha contraria (F.A. Roemer, 1850), an early carboniferous rhynchonellide brachiopod from the Harz Mountains, Germany: a possible successor of Dzieduszyckia? J Paleontol 77:293-303

Głowniak E (2006) The Platysphinctes immigration event: biostratigraphic and paleobiogeographic implications for the Middle Oxfordian (Late Jurassic) seas of Central Europe (MW Germany and Poland). Neues Jahrb Geol Paläontol Abh 241:155-201

Gołębiowska B, Pieczka A, Rzepa G, Matyszkiewicz J, Krajewski M (2010) Iodargyrite from Zalas (Cracow area, Poland) as an indicator of Oligocene-Miocene aridity in Central Europe. Palaeogeogr Palaeoclimatol Palaeoecol 296:130-137

Grădinaru E, Bărbulescu A (1994) Upper Jurassic brachiopod faunas of Central and North Dobrogea (Romania): biostratigraphy, paleoecology and paleobiogeography. Jahrb Geol Bundesanstalt 137:43-84

Gradziński R (1972) Przewodnik geologiczny po okolicach Krakowa. Wydawnictwo Geologiczne, Warszawa (in Polish)

Gradziński R (2009) Geological map of Krakow region without Quaternary and terrestrial tertiary deposits. Wydawnictwo Instytutu Nauk Geologicznych PAN, Kraków

Grassle JF (1985) The ecology of deep-sea hydrothermal vent communities. Adv Mar Biol 23:302-362

Gwinner MP (1976) Origin of the Upper Jurassic limestones of the Swabian Alb (southern Germany). Contrib Sedimentol 5:1-76

Habryn R, Buła Z, Nawrocki J (2014) The Kraków sector of the Kraków-Lubliniec tectonic zone in the light of data obtained from new boreholes of Trojanowice 2 and Cianowice 2. Biul Inst Geol 459:47-60 (in Polish with English summary)

Halliday AN, Davidson JP, Holden P, Owen RM, Olivarez AM (1992) Metalliferous sediments and the scavenging residence time of Nd near hydrothermal vents. Geophys Res Lett 19:761-764

Heliasz Z, Racki G (1980) Ecology of the upper Jurassic brachiopod bed from Julianka, Polish Jura Chain. Acta Geol Pol 30:175-198

Helm C (2005) Riffe und fazielle Entwicklung der florigemma-Bank (Korallenoolith, Oxfordium) im Süntel und östlichen Wesergebirge (NW-Deutschland). Geol Beitr Hannover 7:1-339

Helm C, Schülke I (1999) Ein 'Tethys-Riff' im Korallenoolith (Oxfordium) von Nordwestdeutschland. Zbl Geol Paläontol Teil I 5-6:399-414

Herrmann R (1996) Entwicklung einer oberjurassischen Karbonatplattform: biofazies, Riffe und Sedimentologie im Oxfordium der Zentralen Dobrogea (Ost-Rumanien). Berl Geowiss Abh E19:1-102

Hoffmann M, Matyszkiewicz J (1989) Wykształcenie litologiczne i sedymentacja osadów jury w kamieniołomie Młynka. Przewodnik LX Zjazdu Polskiego Towarzystwa Geologicznego, Państwowy Instytut Geologiczny, Kraków, pp 78-82 (in Polish)

Hryniewicz K, Hagström J, Hammer Ø, Kaim A, Little CTS, Nakrem HA (2015) Late Jurassic-early cretaceous hydrocarbon seep boulders from Novaya Zemlya and their faunas. Palaeogeogr Palaeoclimatol Palaeoecol 436:231-244

Jakubowicz M, Dopieralska J, Belka Z (2015) Tracing the composition and origin of fluids at an ancient hydrocarbon seep (Hollard Mound, Middle Devonian, Morocco): a Nd, REE and stable isotope study. Geochim Cosmochim Acta 156:50-74

James NP, Choquette PW (1984) Limestones-the meteoric diagenetic environment. Geosci Can 11:161-194

Jędrys J, Krajewski M (2007) Wykształcenie i rozwój górnojurajskich osadów okolic Bębła na tle budowy podmezozoicznego podłoża, Wyżyna Krakowska. Tomy Jurajskie 4:95-102 (in Polish)
Jiménez de Cisneros C, Mas JR, Vera JA (1990) A geochemical study of the materials associated with the Jurassic paleokarst of the Sierra Gorda (Internal Subbetic, southern Spain). Rev Soc Geol España 3:391-420

Jiménez de Cisneros C, Mas JR, Vera JA (1991) Geochemistry of speleothems from Jurassic palaeokarts (Subbetic, southern Spain). Sediment Geol 73:191-208

Jurkowska A, Kołodziej B (2013) Taphonomic differentiation of Oxfordian ammonites from the Cracow Upland, Poland. Paläont Z 87:67-82

Kandemir R, Yilmaz C (2009) Lithostratigraphy, facies, and deposition environment of the lower Jurassic Ammonitico Rosso type sediments (ARTS) in the Gümüşhane area, NE Turkey: implications for the opening of the northern branch of the Neo-Tethys Ocean. J Asian Earth Sci 34:586-598

Kendall AC, Tucker ME (1973) Radiaxial fibrous calcite: a replacement after acicular carbonate. Sedimentology 20:365-389

Kidwell SM (1991) The stratigraphy of shell concentrations. In: Allison PA, Briggs DEG (eds) Taphonomy, releasing the data locked in the Fossil Record. Plenum Press, New York, pp 211-290

Kiel S, Glodny J, Birgel D, Bulot LG, Campbell KA, Gaillard C et al (2014) The paleoecology, habitats, and stratigraphic range of the enigmatic Cretaceous brachiopod Peregrinella. PLoS One 9(10):e109260. doi:10.1371/journal.pone.0109260

Kochman A, Matyszkiewicz J (2012) Microbial laminites with coprolites from Upper Jurassic carbonate buildups complex (Kraków-Częstochowa Upland; Poland). Ann Soc Geol Polon 82:331-347

Kołodziej B, Szulc J, Machaniec E, Kędzierski M, Duda M (2010) Injection dykes as evidence of Campanian synsedimentary tectonics on the Cracow Swell, southern Poland. Ann Soc Geol Polon 80:285-301

Koszarski A (1995) Tradycja a nowoczesność w interpretacji warunków powstania wapieni górnej jury krakowskiej. Szczególna rola procesów redepozycji. Studium terenowe. In: Doktor M, Głuszek A, Gmur D, Słomka T (eds) Tradycja a nowoczesność w interpretacjach sedymentologicznych. Materiały Konferencyjne IV Krajowego Spotkania Sedymentologów, Kraków, pp 9-22 (in Polish)

Kozłowski A (1984) Calcium-rich inclusion solutions in fluorite from the Strzegom pegmatites, Lower Silesia. Acta Geol Pol 34:131-138

Kozłowski A, Karwowski Ł, Roedder E (1979) Gas-liquid inclusions in minerals of zinc and lead ores from the Silesia-Cracow region. Prace Inst Geol 95:87-96

Krajewski M (2004) Żyła neptuniczna z Grodziska w Dolinie Prądnika. In: Partyka J, Tyc A (eds) Od Złotego Potoku do Ojcowa szlakiem wyprawy naturalistów w 1854 . Ojcowski Park Narodowy, Spec Pub 2:94-96 (in Polish)

Krajewski M, Matyszkiewicz J (2004) Development and facial architecture of the Upper Jurassic complexes of buildups in the SW part of the Kraków Upland. In: Partyka J (ed) The diversification and transformation of natural and cultural environment of the Kraków-Częstochowa Upland, vol 1. Ojców National Park. Ojców, pp 27-34 (in Polish with English summary)

Krajewski M, Olchowy P, Felisiak I (2014) Lower Kimmeridgian layer with bored and encrusted hiatus concretions (Upper Jurassic, Central Poland): implications for stratigraphy and basin evolution. Ann Soc Geol Polon 84:113-129

Krajewski M, Olchowy P, Felisiak I (2016) Late Jurassic facies architecture of the Złoczew Graben: implications for evolution of the tectonic-controlled northern peri-Tethyan shelf (Upper Oxfordian-Lower Kimmeridgian, Poland). Facies 62:4. doi:10.1007/ s10347-015-0455-3

Krawczyński C (2008) The Upper Oxfordian (Jurassic) thecideide brachiopods from the Kujawy area, Poland. Acta Geol Pol 58:395-406 
Kutek J (1994) Jurassic tectonic events in south-eastern cratonic Poland. Acta Geol Pol 44:167-221

Land LS, Goreau TF (1970) Submarine lithification of Jamaican Reefs. J Sediment Petrol 40:457-460

Lazăr I, Panaiotu CE, Grigore G, Sandy MR, Peckmann J (2011) An unusual brachiopod assemblage in a Late Jurassic (Kimmeridgian) stromatactis mud-mound of the Eastern Carpathians (Hăghimaş Mountains), Romania. Facies 57:627-647

Lee DE, Gregory MR, Lüter C, Zezina ON, Robinson JH, Christie DM (2008) Melvicalathis, a new brachiopod genus (Terebratulida: Chlidonophoridae) from deep sea volcanic substrates, and the biogeographic significance of the mid-ocean ridge system. Zootaxa 1866:138-150

Little CTS, Herrington RJ, Maslennikov VV, Morris NJ, Zaykov VV (1997) Silurian hydrothermal vent community from the southern Urals, Russia. Nature 385:146-148

Little CTS, Herrington RJ, Haymon RM, Danelian T (1999) Early Jurassic hydrothermal vent community from the Franciscan Complex, San Rafael Mountains, California. Geology 27:167-170

Little CTS, Danelian T, Herrington RJ, Haymon RM (2004) Early Jurassic hydrothermal vent community from the Franciscan Complex, California. J Paleontol 78:542-559

Longman MW (1980) Carbonate diagenetic textures from nearshore diagenetic environments. AAPG Bull 64:461-487

Łuczyński P (2001) Development history of Middle Jurassic neptunian dykes in the High-Tatric series, Tatra Mountains, Poland. Acta Geol Pol 51:237-252

Martire L (1996) Stratigraphy, facies and synsedimentary tectonics in the Jurassic Rosso Ammonitico Veronese (Altopiano di Asiago, NE Italy). Facies 35:209-236

Matyja BA, Ziółkowski P (2014) Upper Jurassic stratigraphy and facies differentiation - a case study of the Cianowice 2 and Trojanowice 2 boreholes (Olkusz Upland and Krzeszowice Graben borderland). Biul Inst Geol 459:93-108 (in Polish with English summary)

Matyszkiewicz J (1993) Genesis of stromatactis in an Upper Jurassic carbonate buildup (Młynka; Cracow Region, southern Poland); internal reworking and erosion of organic growth cavities. Facies 28:87-96

Matyszkiewicz J (1996) The significance of Saccocoma-calciturbidites for the analysis of the polish epicontinental Late Jurassic Basin: an example from the Southern Cracow-Wieluń Upland (Poland). Facies 34:23-40

Matyszkiewicz J (1997) Stromatactis cavities and stromatactis-like cavities in the Upper Jurassic carbonate buildups at Młynka and Zabierzów (Oxfordian, southern Poland). Ann Soc Geol Polon 67:45-55

Matyszkiewicz J (1999) Sea-bottom relief versus differential compaction in ancient platform carbonates: a critical reassessment of an example from Upper Jurassic of the Cracow-Wielun Upland. Ann Soc Geol Polon 69:63-79

Matyszkiewicz J, Krajewski M (1996) Lithology and sedimentation of Upper Jurassic massive limestones near Bolechowice, Kraków-Wieluń Upland, south Poland. Ann Soc Geol Polon 66:285-301

Matyszkiewicz J, Krajewski M, Żaba J (2006a) Structural control on the distribution of Upper Jurassic carbonate buildups in the Kraków-Wieluń Upland (South Poland). Neues Jahrb Geol Paläont Mon 3:182-192

Matyszkiewicz J, Krajewski M, Kędzierski J (2006b) Origin and evolution of an Upper Jurassic complex of carbonate buildups from Zegarowe Rocks (Kraków-Wieluń Upland, Poland). Facies $52: 249-263$
Matyszkiewicz J, Świąder J, Żaba J (2007) Przejawy późnojurajskiej tektoniki synsedymentacyjnej w rejonie Kamienia. Tomy Jurajskie 4:63-70 (in Polish)

Matyszkiewicz J, Kochman A, Duś A (2012) Influence of local sedimentary conditions on development of microbialites in the Oxfordian carbonate buildups from the southern part of the Kraków-Częstochowa Upland (south Poland). Sediment Geol 263-264:109-132

Matyszkiewicz J, Kochman A, Rzepa G, Gołębiowska B, Krajewski M, Gaidzik K, Żaba J (2015a) Epigenetic silicification of the Upper Oxfordian limestones in the Sokole Góry (KrakówCzęstochowa Upland); relation to facies development and tectonics. Acta Geol Pol 65:181-203

Matyszkiewicz J, Felisiak I, Hoffman M, Kochman A, Kołodziej B, Krajewski M, Olchowy P (2015b) Transgressive Callovian succession and Oxfordian microbial-sponge carbonate buildups in the Kraków Upland. In: Haczewski G (ed) Guidebook for field trips accompanying 31st IAS meeting of sedimentology held in Kraków on 22nd-25th of June 2015, Kraków, pp 51-74

Molina JM, Ruiz-Ortiz PA, Vera JA (1995) Neptunian dykes and associated features in southern Spain: mechanics of formation and tectonic implications. Sedimentology 42:957-969

Montenat C, Barrier P, Ott d'Estevou P, Hibsch C (2007) Seismites: an attempt at critical analysis and classification. Sediment Geol 196:5-30

Morawska A (1997) The Lubliniec fracture zone: boundary of the Upper Silesia and Malopolska Massifs, southern Poland. Ann Soc Geol Polon 67:429-437

Mounji D, Bourque PA, Savard MM (1998) Hydrothermal origin of Devonian conical mounds (kesskess) of Hamar Lakhdad Ridge, Anti-Atlas, Morocco. Geology 26:1123-1126

Nawrocki J, Fanning M, Lewandowska A, Polechońska O, Werner T (2008) Palaeomagnetism and the age of the Cracow volcanic rocks (S Poland). Geophys J Int 174:475-488

Nieto LM, Reolid M, Molina JM, Ruiz-Ortiz PA, Jiménez-Millán J, Rey J (2012) Evolution of pelagic swells from hardground analysis (Bathonian-Oxfordian, Eastern External Subbetic, southern Spain). Facies 58:389-414

Nitzopoulos G (1974) Faunistisch-ökologische, stratigraphische und sedimentologische Untersuchungen am SchwammstotzenKomplex bei Spielberg am Hahnenkamm (Ob. Oxfordien, Südliche Frankenalb). Stutt Beitr Naturk 16:1-143

Nowak J (2014) Jaskinia w Mącznej Skale Duża. Jaskinie 4:33-35 (in Polish)

Olivier N, Boyet M (2006) Rare earth and trace elements of microbialites in Upper Jurassic coral- and sponge-microbialite reefs. Chem Geol 230:105-123

Olóriz F, Reolid M, Rodríguez-Tovar FJ (2002) Fossil assemblages, lithofacies, taphofacies and interpreting depositional dynamics in the epicontinental Oxfordian of the Prebetic Zone, Betic Cordillera, southern Spain. Palaeogeogr Palaeoclimatol Palaeoecol 185:53-75

Olóriz F, Reolid M, Rodríguez-Tovar FJ (2006) Approaching trophic structure in Late Jurassic neritic shelves: a western Tethys example from southern Iberia. Earth Sci Rev 79:101-139

Peckmann J, Campbell KA, Walliser OH, Reitner J (2007) A late Devonian hydrocarbon-seep deposit dominated by dimerelloid brachiopods, Morocco. Palaios 22:114-122

Peckmann J, Kiel S, Sandy MR, Taylor DG, Goedert JL (2011) Mass occurrences of the brachiopod Halorella in Late Triassic methane-seep deposits, Eastern Oregon. J Geol 119:207-220

Pittet B, Strasser A (1998) Long-distance correlations by sequence stratigraphy and cyclostratigraphy: examples and implications (Oxfordian from the Swiss Jura, Spain, and Normandy). Geol Rundsch 86:852-874 
Reinhold C (1999) Dog-tooth cements: indicators of different diagenetic environments. Zbl Geol Paläontol I 1997:1221-1235

Reinhold C, Kaufmann B (2010) Sea-level changes as controlling factor of early diagenesis: the reefal limestones of Adnet (Late Triassic, Northern Calcareous Alps, Austria). Facies 26:231-248

Reolid M, Abad I (2014) Glauconitic laminated crusts as a consequence of hydrothermal alteration of Jurassic pillow-lavas from Median Subbetic (Betic Cordillera, S Spain): a microbial influence case. J Ib Geol 40:389-408

Reolid M, Molina JM (2010) Serpulid-Frutexites assemblage from shadow-cryptic environments in Jurassic marine caves (Betic Cordillera, South Spain). Palaios 25:468-474

Reolid M, Nieto LM, Rey J (2010) Taphonomy of cephalopod assemblages from Middle Jurassic hardgrounds of pelagic swells (South-Iberian palaeomargin, Western Tethys). Palaeogeogr Palaeoclimatol Palaeoecol 292:257-271

Richter DK, Neuser RD, Schreuer J, Gies H, Immenhauser A (2011) Radiaxial-fibrous calcites: a new look at an old problem. Sediment Geol 239:23-36

Rioult M, Dugué O, Jan du Chêne R, Ponsot C, Fily G, Moron JM, Vail PR (1991) Outcrop sequence stratigraphy of the AngloParis Basin, middle to upper Jurassic (Normandy, Maine, Dorset). B Cent Rech Expl 15:101-194

Roedder E (1984) Fluid inclusions. Reviews in mineralogy, 12. Mineralogical Society of America, Washington, D.C., p 646

Różycki S (1948) Remarks about Upper Jurassic Rhynchonellidae of the Crakow-Częstochowa Chain. Biul Inst Geol 42:16-40 (in Polish with English summary)

Sandy MR (1988) Tithonian brachiopods. Mém Soc Géol Fr $154: 71-74$

Sandy MR (1995) A review of some Palaeozoic and Mesozoic brachiopods members of cold seep chemosynthetic communities: 'unusual' palaeoecology and anomalous palaeobiogeographic patterns explained. Földtani Közlöny Bull Hung Geol Soc $125: 241-258$

Sandy MR (2010) Brachiopods from ancient hydrocarbon seeps and hydrothermal vents. In: Kiel S (ed) The vent and seep biota. Aspects from microbes to ecosystems, vol 33. Topics in Geobiology, pp 107-133

Sandy MR, Campbell KA (1994) New rhynchonellid brachiopod genus from Tithonian (Upper Jurassic) cold seeps deposits of California and its paleoenvironmental setting. J Paleontol 68:1243-1252

Sandy MR, Hryniewicz K, Hammer O, Nakrem HA, Little CTS (2014) Brachiopods from the Late Jurassic-Early Cretaceous hydrocarbon seep deposits, central Spitsbergen, Svalbard. Zootaxa 3884:501-532

Santantonio M (1993) Facies associations and evolution of pelagic carbonate platform/basin systems: examples from the Italian Jurassic. Sedimentology 40:1039-1067

Seyed-Emami K, Fürsich F, Wilmsen M, Majidifard MR, Shekarifard A (2008) Lower and middle Jurassic ammonoids of the Shemshak Group in Alborz, Iran, and their palaeobiogeographical and biostratigraphical importance. Acta Palaeontol Pol 53:237-260

Sidorczuk M, Lewandowski M, Bełka Z (2009) Rift-related environmental change in the northern Tethys based on $\mathrm{Nd}$ i Sr isotopes in the middle and upper Jurassic carbonates of the Pieniny Klippen Belt. Geologia Kwartalnik AGH 35:97-98

Smart PL, Palmer RJ, Whitaker F, Wright VP (1988) Neptunian dikes and fissure fills: an overview and account of some modern examples. In: James NP, Choquette PW (eds) Paleokarst. Springer, New York, pp 149-163

Stanier RY, Cohen-Bazire G (1977) Phototrophic prokaryotes: the cyanobacteria. In: Starr MP, Ingraham JL, Balows A (eds.) Annu Rev Microbiol 31:225-274
Steele-Petrovič HM (1976) Brachiopod food and feeding processes. Paleontology 19:417-436

Steele-Petrovič HM (1979) The physiological differences between articulate brachiopods and filter-feeding bivalves as a factor in the evolution of marine level-bottom communities. Palaeontology 22:101-134

Stille P, Fischer H (1990) Secular variation in the isotopic composition of $\mathrm{Nd}$ in Tethys seawater. Geochim Cosmochim Acta 54:3139-3145

Stille P, Steinmann M, Riggs SR (1996) Nd isotope evidence for the evolution of the paleocurrents in the Atlantic and Tethys Oceans during the past $180 \mathrm{Ma}$. Earth Planet Sci Lett 144:9-19

Stüben D, Glasby GP (1999) Geochemistry of shallow submarine hydrothermal fluids from Paleochori Bay, Milos, Aegean Sea. Explor Min Geol 8:273-287

Sulser H, Meyer C (1998) Taxonomy and palaeoecology of terebratulid brachiopods (Sellithyris subsella-group) from the Late Jurassic of northwestern Switzerland. Eclogae Geol Helv 91:439-451

Tarasov VG, Gebruk AV, Mironov AN, Moskalev LI (2005) Deep-sea and shallow-water hydrothermal vent communities: two different phenomena? Chem Geol 224:5-39

Taviani M (1994) The "calcari a Lucina" microfauna reconsidered: deep-sea faunal oases from Miocene-age cold vents in the Romagna Apennine, Italy. Geo Mar Lett 14:185-191

Tomašových A (2006) Brachiopod and bivalve ecology in the Late Triassic (Alps, Austria): onshore-offshore replacements caused by variations in sediment and nutrient supply. Palaios 21:344-368

Tunnicliffe V (1988) Biogeography and evolution of hydrothermalvent fauna in the eastern Pacific Ocean. Proc R Soc Lond B Biol Sci 233:347-366

Tunnicliffe V (1991) The biology of hydrothermal vents: ecology and evolution. Oceanogr Mar Biol 29:319-407

Tunnicliffe V (1992a) Hydrothermal-vent communities of the deep sea. Am Sci 80:336-349

Tunnicliffe V (1992b) The nature and origin of the modern hydrothermal ventfauna. Palaios 7:338-350

Van Dover CL (2000) The ecology of deep-sea hydrothermal vents. Princeton University Press, Princeton, p 424

Wagenplast P (1972) Ökologische Untersuchung der Fauna aus Bankund Schwammfazies des Weissen Jura der Schwäbischen Alb. Arbeiten aus dem Institut für Geologie und Paläontologie der Universität Stuttgart, NF, vol 67, pp 1-99

Waldken GM, Berry JR (1984) Syntaxial overgrowths in muddy crinoidal limestones: cathodoluminescence sheds new light on an old problem. Sedimentology 31:251-267

Wall GR, Jenkyns HC (2004) The age, origin and tectonic significance of Mesozoic sediment-filled fissures in the Mendip Hills (south-west England): implications for extension models and Jurassic sea-level curves. Geol Mag 141:471-504

Wendt J (1971) Genese und Fauna submariner sedimentärer Spaltenfällungen im Mediterranen Jura. Palaeontogr Abt 136:121-192

Wetzel A, Allenbach R, Allia V (2003) Reactivated basement structures affecting the sedimentary facies in a tectonically "quiescent" epicontinental basin: an example from NW Switzerland. Sediment Geol 157:153-172

Wieczorek J, Krobicki M (1994) An example of Oxfordian extension on peri-Tethyan platform: neptunian dykes infilled by brachiopod shells from Młynka quarry (Kraków Upland). In: 3rd international meeting of peri-Tethyan epicratonic basins (IGCP 343), Abstracts, pp 25-26

Wieczorek J, Olszewska B (2001) Cretaceous neptunian dykes of the Cracow Upland. Geol Saxon 46(47):139-147

Wierzbowski A (1970) Stratigraphic significance of superfamily Rhynchonellacea (brachiopoda) in the Upper Jurassic of 
Poland. Acta Geol Pol 20:91-100 (in Polish with English summary)

Winterer EL, Sarti M (1994) Neptunian dykes and associated features in southern Spain: mechanics of formation and tectonic implications. Sedimentology 41:1109-1132

Winterer EL, Metzler CV, Sati M (1991) Neptunian dykes and associated breccias (Southern Alps, Italy and Switzerland): role of gravity sliding in open and closed systems. Sedimentology 38:381-404

Wiśniewska-Żelichowska M (1971) Fauna of the Jurassic bioherms at Rudniki near Częstochowa (Central Poland). Biul Inst Geol 243:5-77 (in Polish with English summary)
Wrzak J (2014) Jaskinia Duża okiem geologa. Jaskinie 4:35-36 (in Polish)

Żaba J (1999) The structural evolution of Lower Palaeozoic succession in the Upper Silesia Block and Małopolska Block border zone, southern Poland. Prace Państw Inst Geol 166:1-162 (in Polish with English summary)

Ziegler PA (1990) Geological atlas of Central and Western Europe. Shell Internationale Petroleum Maatschapij, The Hague

Ziółkowski P (2007) Stratygrafia i zróżnicowanie facjalne górnej jury wschodniej części Wyżyny Krakowskiej. Tomy Jurajskie 4:2538 (in Polish) 